\title{
Fluorescent nucleobase analogues for base-base FRET in nucleic acids: synthesis, photophysics and applications
}

\author{
Mattias Bood ${ }^{\ddagger 1}$, Sangamesh Sarangamath ${ }^{\ddagger 2}$, Moa S. Wranne ${ }^{2}$, Morten Grøtli ${ }^{1}$ \\ and L. Marcus Wilhelmsson ${ }^{* 2}$
}

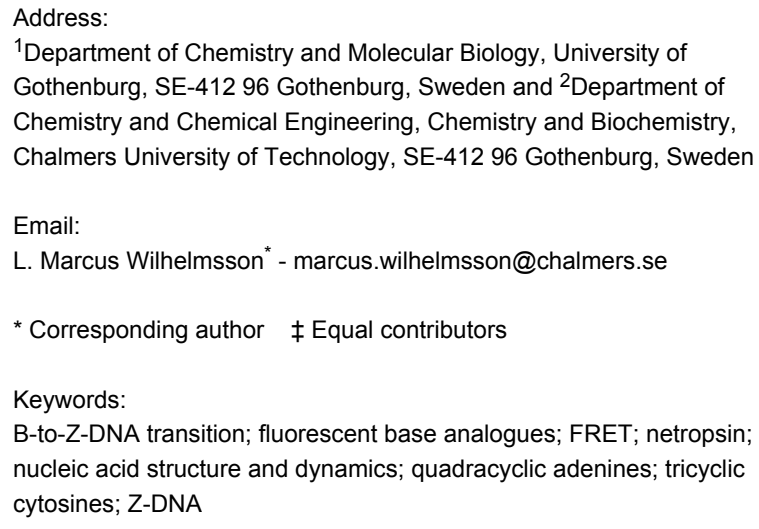

Beilstein J. Org. Chem. 2018, 14, 114-129. doi:10.3762/bjoc. 14.7

Received: 08 November 2017

Accepted: 22 December 2017

Published: 10 January 2018

This article is part of the Thematic Series "Nucleic acid chemistry II".

Guest Editor: H.-A. Wagenknecht

(c) 2018 Bood et al.; licensee Beilstein-Institut.

License and terms: see end of document.

\begin{abstract}
Förster resonance energy transfer (FRET) between a donor nucleobase analogue and an acceptor nucleobase analogue, base-base FRET, works as a spectroscopic ruler and protractor. With their firm stacking and ability to replace the natural nucleic acid bases inside the base-stack, base analogue donor and acceptor molecules complement external fluorophores like the Cy-, Alexa- and ATTO-dyes and enable detailed investigations of structure and dynamics of nucleic acid containing systems. The first base-base FRET pair, $\mathrm{tC}^{\mathrm{O}}-\mathrm{tC}_{\text {nitro }}$, has recently been complemented with among others the adenine analogue FRET pair, $\mathrm{qAN} 1-\mathrm{qA}_{\text {nitro }}$, increasing the flexibility of the methodology. Here we present the design, synthesis, photophysical characterization and use of such base analogues. They enable a higher control of the FRET orientation factor, $\kappa^{2}$, have a different distance window of opportunity than external fluorophores, and, thus, have the potential to facilitate better structure resolution. Netropsin DNA binding and the B-to-Z-DNA transition are examples of structure investigations that recently have been performed using base-base FRET and that are described here. Base-base FRET has been around for less than a decade, only in 2017 expanded beyond one FRET pair, and represents a highly promising structure and dynamics methodology for the field of nucleic acids. Here we bring up its advantages as well as disadvantages and touch upon potential future applications.
\end{abstract}

\section{Review}

\section{Introduction}

The importance of nucleic acid structure and dynamics in the understanding of vital processes in living organisms has led to the development of a large number of techniques for such investigations. Among the most significant ones are NMR [1] and
X-ray crystallography [2]. Both techniques offer a high structure resolution and NMR can also provide information on dynamics. However, there are occasions where NMR and X-ray crystallography suffer from drawbacks: the sample amount 
requirement and biomolecular size restriction for NMR and the difficulties in obtaining crystals and the obvious lack of solution dynamics for X-ray crystallography. An important method for biomolecular structure and dynamics investigations that complements NMR and X-ray, normally at lower resolution, is Förster resonance energy transfer (FRET) $[3,4]$. FRET and especially single-molecule FRET (as an effect of a low number of biomolecules under study) has the advantage of enabling structure and dynamics investigations in living cells $[3,5,6]$ FRET is a process that depends on the radiationless energy transfer between a donor and an acceptor molecule [7]. The reason that it can be used as a structure and dynamics technique is that it depends heavily on the distance and relative orientation between the donor and acceptor. Typical distances that can be monitored range between $15-90 \AA$ which well match the dimensions of biomolecules. The efficiency of an energytransfer process ( $E$, between 0 and $100 \%)$ can be established using either steady-state or time-resolved fluorescence spectroscopy by comparing fluorescence properties with and without the acceptor molecule present. This efficiency $(E)$ depends on the distance $\left(R_{\mathrm{DA}}\right)$ between the donor and acceptor as described in Equation 1:

$$
E=R_{0}^{6} /\left(R_{0}^{6}+R_{\mathrm{DA}}{ }^{6}\right)
$$

where $R_{0}$ is the Förster distance (Equation 2), a characteristic distance of the donor-acceptor pair at which the energy transfer efficiency $(E)$ is $50 \%$.

$$
R_{0}=0.211\left(J_{\mathrm{DA}} \kappa^{2} n^{-4} \Phi_{\mathrm{D}}\right)^{1 / 6} \text { in } \AA
$$

As can be seen in Equation 2 the Förster distance depends on the quantum yield of the donor $\left(\Phi_{\mathrm{D}}\right)$, the donor/acceptor spectral overlap integral $\left(J_{\mathrm{DA}}\right.$, overlap between energies of donor emission and acceptor absorption envelope), the refractive index of the medium $(n)$, and importantly the geometric factor ( $\kappa$, Equation 3). This factor takes the relative orientation of the transition dipole moments of the donor and acceptor into account and, thus, introduces an orientation dependence to $R_{0}$ and consequently also to the energy transfer efficiency, $E$. The orientation factor, which ranges between 0 and 4 , is governed by Equation 3:

$$
\kappa=\mathbf{e}_{1} \cdot \mathbf{e}_{2}-3\left(\mathbf{e}_{1} \cdot \mathbf{e}_{12}\right)\left(\mathbf{e}_{12} \cdot \mathbf{e}_{2}\right)
$$

where $\mathbf{e}_{1}$ and $\mathbf{e}_{2}$ are the unit vectors of the donor and acceptor transition dipole moments and $\mathbf{e}_{12}$ the unit vector between their centers (see Figure 1a; $\kappa$ can also be expressed using the angles in Figure 1a: $\kappa=\cos \varphi-3 \cos \theta \cos \omega)$.
In most FRET applications, an orientation factor $\kappa^{2}$ of $2 / 3$ is used. This is the correct value for freely rotating, isotropic donor and acceptor molecule orientations (Figure 1b). With an isotropic orientation of the donor and acceptor throughout the experiment the energy transfer efficiency $(E)$ is directly related to the distance and the technique becomes a spectroscopic ruler. Such an assumption is often made, both correctly and incorrectly [8-10], for covalently attached external nucleic acid fluorophores like Cy-, Alexa- and ATTO-dyes. This provides a powerful means for measuring long distance ranges (typically 35-90 A) in nucleic acid-containing systems. However, with the free rotation of the donor and the acceptor the ability of FRET to monitor changes in orientation between them is also lost. With virtually static donor and acceptor molecules (Figure 1c) $\kappa^{2}$ can be used to improve the structure resolution via the introduction of orientation information, i.e., FRET will also work as a spectroscopic protractor. Several investigations, including the ones by Tor et al. [11], Lewis et al. [12] and Lilley et al. [13], have taken significant steps in the direction of introducing orientational information into nucleic acid FRET. Recently, our group took this progress one step further and introduced base-base FRET [14], where the donor and acceptor molecules are nucleobase analogues $[15,16]$. With the donor and acceptor molecules rigidly stacked in the base-stack of the nucleic acid (Figure 1c) this approach provides highly accurate orientation information and has the potential to increase the structure and dynamics information obtained in a nucleic acid FRET experiment. Later Asanuma et al. introduced base-stacked aromatic moieties [17], not working as nucleobase analogues, which also can be used to provide information about orientation.

In this review we will focus on the FRET between fluorescent base analogues, i.e., base-base FRET, the theory behind it, the increased accuracy in orientation factor $\kappa^{2}$ as an effect of their position inside the base-stack, other advantages and disadvantages compared to FRET in nucleic acids using external fluorophores like Cy-, Alexa- and ATTO-dyes as well as finally summarize some of its recent applications. The field started less than a decade ago with the introduction of the first fluorescent nucleobase analogue FRET pair, $\mathrm{tC}^{\mathrm{O}}-\mathrm{tC}_{\text {nitro }}$, and we divide this review into three parts: the first one dealing with the synthesis of the key players of base-base FRET, i.e., the base analogue donor and acceptor molecules, the second one dealing with their photophysical properties and the third one dealing with their application in studying nucleic acid-containing systems.

\section{Synthesis of fluorescent base analogues}

The development of synthesis methods of nucleobase analogues remains a challenge. This is mainly due to the presence of multiple reactive functional groups both on the nucleobase as well as the sugar moiety and requires the introduction of orthog- 


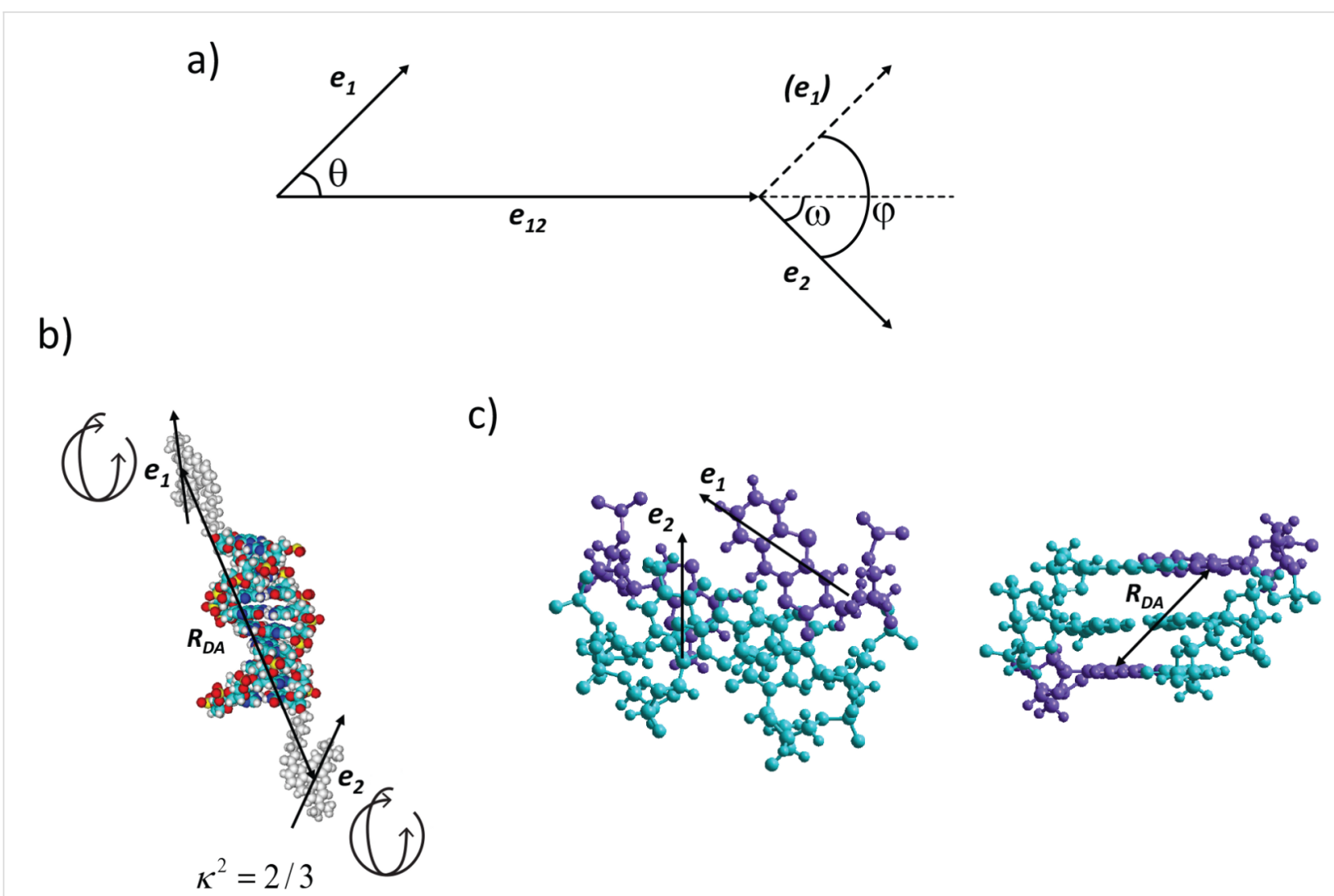

Figure 1: a) Angles and unit vectors used to define the relative orientations of the donor and acceptor transition dipole moments (e $\left.\mathbf{e}_{1}, \mathbf{e}_{2}\right)$ and the separating vector $\left(\mathbf{e}_{12}\right)$. b) Illustration of the external fluorophores covalently attached to a DNA and their transition dipole moments $\left(\mathbf{e}_{1}, \mathbf{e}_{2}\right)$ with free rotation relative to the DNA, i.e., isotropic orientation, $\mathrm{k}^{2}=2 / 3 . R_{\mathrm{DA}}$ is the separation between donor and acceptor. c) DNA top-view (left) and sideview (right) illustrating the typical situation for the virtually static transition dipole moments $\left(\mathbf{e}_{1}, \mathbf{e}_{2}\right)$ of fluorescent base analogues in base-base FRET and the distance separating them $\left(R_{\mathrm{DA}}\right)$.

onal protection groups. A careful consideration of protection groups is paramount as an extensive use adds additional steps as well as complexity to the synthesis. The design and synthesis of fluorescent nucleobase analogues (FBAs) add on additional challenges such as obtaining features that introduce useful photophysical properties, for example, extended conjugation. As an effect of the need for hydrogen bonding properties, size restriction and sterical effects these demands are often conflicting $[15,18,19]$. However, there is an increasing number of exceptions to this and since the pioneering work of Ward et al. on adenine analogues [20] a whole range of small modifications to nucleobases, such as the 8-vinyldeoxyadenosine [21], has led to the introduction of fluorescence. Considering the differences in the structures of purines and pyrimidines, adenine is unique amongst the natural bases as it offers several sites for modifications: $\mathrm{C} 2, \mathrm{C} 8$, the $\mathrm{C} 6$ exocyclic amino functionality and the vastly explored N7 to $\mathrm{C} 7$ substitution leading to 7-deazaadenines. On the contrary, for guanine only the $\mathrm{C} 8$ and the $\mathrm{C} 2$ exocyclic amine are directly accessible for modifications as well as the previously mentioned 7-deaza substitution. Looking at the monocyclic pyrimidines, only the $\mathrm{C} 5$ and $\mathrm{C} 6$ positions are available for modifications without directly perturbing the basepairing properties. The subtle differences between the nucleobases within a class could lead one to believe that the chemistry developed for modifications of adenine would translate easily to guanine. Unfortunately, the variety of functional groups requires different protection group strategies and, moreover, changes the reactivity of the nucleobase. Since the discovery of the gold standard of fluorescent base analogues, 2-AP, a multitude of adenine FBAs has emerged [22]. Notable recent examples of adenine FBAs (see Figure 2 for chemical structures) include $\mathrm{C} 8$ to $\mathrm{S} 8$ thio-RNA analogue ${ }^{\text {th }} \mathrm{A}$ [23], the C8-naphtalene substituted adenines ${ }^{\mathrm{cn}} \mathrm{A}$ and ${ }^{\mathrm{dn}} \mathrm{A}$ [24], as well as our own quadracyclic qAN1 [25]. A handful of fluorescent guanine analogues has been synthesized and characterized and includes the recent turn-on probe BFdG, 3-MI, $2 \mathrm{PyG}$, as well as the emissive RNA analogue ${ }^{\text {th }} \mathrm{G}[23,26-28]$. Some notable pyrimidine analogues include our tricyclic analogues $\mathrm{tC}$ and $\mathrm{tC}^{\mathrm{O}}$ [29-31], pyrrolo-dC [32] and its derivatives [33] as well as ${ }^{\text {th }} U,{ }^{\text {th }} \mathrm{C}$ [23] and ${ }^{\mathrm{DMA}} \mathrm{C}$ [34]. Apart from $\mathrm{tC}, \mathrm{tC}^{\mathrm{O}}$, qAN1 and ${ }^{\text {th }} \mathrm{G}, \mathrm{FBAs}$ have not yet been utilized in base-base FRET applications. However, the brightest of these FBAs combined with a matching donor or 
<smiles>[R]n1cc2c(nc1=O)Nc1ccccc1S2</smiles>

tC<smiles>[R]n1cc2c(nc1=O)Nc1ccccc1O2</smiles>

$\mathrm{tC}^{\mathrm{O}}$<smiles>[R]n1cc2c(nc1=O)Nc1ccc([N+](=O)[O-])cc1S2</smiles>

$\mathrm{tC}_{\text {nitro }}$<smiles>[R1]n1cc2c3c(ncnc31)Nc1ncccc1-2</smiles><smiles>[R]n1cc2c3c(ncnc31)Nc1ccc([N+](=O)[O-])cc1-2</smiles>

$\mathrm{qA}_{\text {nitro }}$<smiles>[R1]n1cnc2cnc(N)nc21</smiles>

2-AP<smiles>[R]c1scc2c(N)ncnc12</smiles>

${ }^{\text {th }} \mathrm{A}$<smiles>[Z17]n1c(C#C[I-]2Cc3ccccc32)nc2c(N)ncnc21</smiles>

${ }^{\mathrm{cn}} \mathrm{A}$<smiles>[R1]n1c(C#C[I-]2C=Cc3ccccc32)nc2c(N)ncnc21</smiles>

${ }^{\mathrm{dn}} \mathrm{A}$<smiles>[R]n1cc(-c2cc3ccccc3o2)c2c(=O)[nH]c(N)nc21</smiles>

$\mathrm{BF}_{\mathrm{dG}}$<smiles>[R1]n1c(=O)cnc2c(=O)n(C)c(N)nc21</smiles>

3-MI<smiles>[R]n1c(-c2ccccn2)nc2c(=O)[nH]c(N)nc21</smiles>

2PyG<smiles>[R]c1scc2c(=O)[nH]c(N)nc12</smiles>

${ }^{\text {th }} G$<smiles>[R]n1c(=O)[nH]c(=O)c2cscc21</smiles>

the<smiles>[R]n1c(=O)nc(N)c2cscc21</smiles>

${ }^{\text {th }} \mathrm{C}$

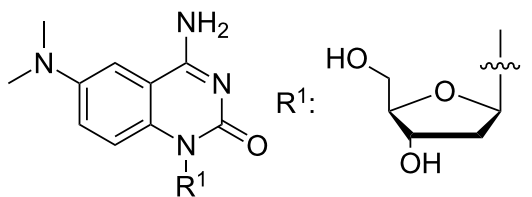

$\mathrm{R}^{1}$

${ }^{\text {DMAC }}$

Figure 2: Notable recent examples of fluorescent base analogues. For ${ }^{\mathrm{c}} \mathrm{A}$ and ${ }^{\mathrm{dn}} \mathrm{A}$ the attachment point to the substituted naphthalene moiety has been varied.

acceptor molecule could potentially also be used in base-base FRET in the future.

\section{Synthesis of cytosine analogues for base-base FRET in DNA}

We have put considerable effort into developing the family of fluorescent base analogues known as the tricyclic cytosines ( $\mathrm{tC}$ ) [14,29-31,35-38]. The aromatic core of $\mathrm{tC}$ was first prepared by Roth et al. in 1963 as part of a study to obtain pharmacologically active compounds structurally similar to phenothiazines [39]. Compound 1 (Scheme 1) was readily prepared from condensation of 2,4-dihydroxy-5-bromopyrimidine with 2-aminothiophenol under basic conditions at elevated temperatures and was obtained in $40 \%$ isolated yield [40]. Ring-closing of compound $\mathbf{1}$ to obtain compound $\mathbf{2}$ was achieved by an acid-catalyzed cyclization which was found to be general for a large set of 4-hydroxy-5-(o-aminoarylthio)pyrimidines [39]. The mechanism was thought to proceed via protonation of a pyrimidine ring nitrogen which activates it to nucleophilic attack by an unprotonated anilino nitrogen on the positive $\mathrm{C} 4$ of the pyrimidine ring which carries the hydroxy group. The formed com-

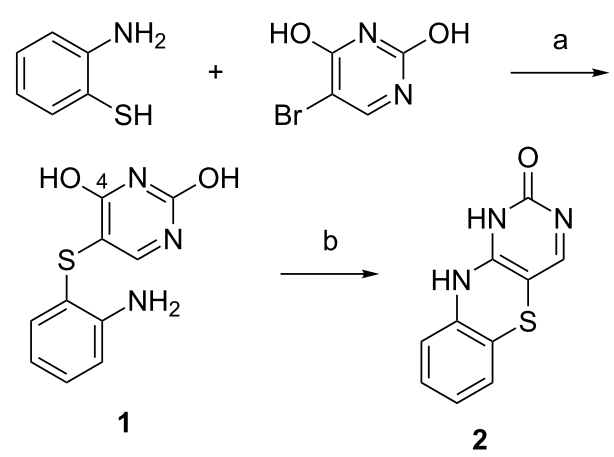

Scheme 1: Synthesis of the tricyclic cytosine aromatic core [39]. (a) Ethylene glycol, $\mathrm{K}_{2} \mathrm{CO}_{3}, 120^{\circ} \mathrm{C}, 1 \mathrm{~h}, 40 \%$; (b) EtOH, $1 \mathrm{M} \mathrm{HCl}$, reflux, $16 \mathrm{~h}, 75 \%$. 
plex eliminates water and yielded the cyclization product in $75 \%$ after isolation.

In an effort to increase the thermodynamic stability of oligonucleotide duplexes for antisense purposes, Lin et al. turned to size-expanded nucleobase analogues [41]. To this end they wanted to use the aromatic ring system previously developed by Roth et al. [39] as a nucleobase analogue to furnish greater $\pi-\pi$ interactions with the natural bases and possibly also to increased hydrophobic effects. A new strategy for the preparation of $\mathrm{tC}$ analogues was used, starting from 5-iodo or 5-bromo-2'deoxyuridine (Scheme 2) [41]. Compounds 3 and 4 were reacted with acetic anhydride in pyridine to protect the deoxyribose hydroxy groups. The $\mathrm{O} 4$ position was then activated by sulfonylation using 2-mesitylenesulfonyl chloride. The subsequent condensation with the appropriate 2-aminothiophenol or 2-aminophenol afforded compounds 5 and $\mathbf{6}$, respectively. Refluxing 5 with $t$-BuOK in EtOH generated 7 in 38\% isolated yield. When 6 was treated with the same cyclization conditions as $\mathbf{5}$ only dehalogenation was observed. Compound $\mathbf{8}$ was obtained by first removing the acetyl protecting groups using ammonia in $\mathrm{MeOH}$, followed by cyclization by refluxing deprotected 8 with $\mathrm{KF}$ in EtOH. Presumably, a transient Michael addition of the hydroxy group to the C6 position of compound 6 increases the reactivity of the $\mathrm{C} 5$ position towards substitution. Standard dimethoxytritylation of compounds $\mathbf{7}$ and $\mathbf{8}$ furnished product 9, which was used in the next step without isolation and $\mathbf{1 0}$ in 50\% yield over three steps, respectively. Lastly, phosphitylation yielded the corresponding $\mathrm{H}$-phosphonates $\mathbf{1 1}$ in $71 \%$ yield over two steps and $\mathbf{1 2}$ in $80 \%$ yield (Scheme 2 ).

In 2001, tC was reported as a fluorescent nucleobase analogue [39]. The tricyclic core was synthesized as reported by Roth et al., and subsequently functionalized with a carboxylic acid handle for PNA labeling [39]. In 2003, tC [35] was synthesized bearing a 2 '-deoxyribose functionality and thoroughly photophysically characterized (vide infra). tC was later functionalized with a phosphoramidite and incorporated into oligonucleotides [30]. However, the fully detailed synthesis with complete characterization was published in 2007 as a Nature Protocol paper [37]. The aromatic core of $\mathrm{tC}$ was prepared according to the procedure of Roth et al. (Scheme 1), followed by a glycosylation using the sodium-salt method as later also performed in the synthesis of $\mathrm{tC}_{\text {nitro }}$ in 2009 (reaction c, Scheme 3) [14,42]. The synthesis was finished by standard DMTr protection and phosphitylation furnishing $\mathrm{tC}$ deoxyribose phosphoramidite in a total of $2.1 \%$ yield over 6 steps [43,44]. In 2008, the oxo-analogue $\mathrm{tC}^{\mathrm{O}}$, which Lin et al. initially prepared in 1995 [41], was re-synthesized in order to characterize its photophysical properties, using the same procedure except that $p$-toluoyl protecting groups rather than acetyl were used [31].

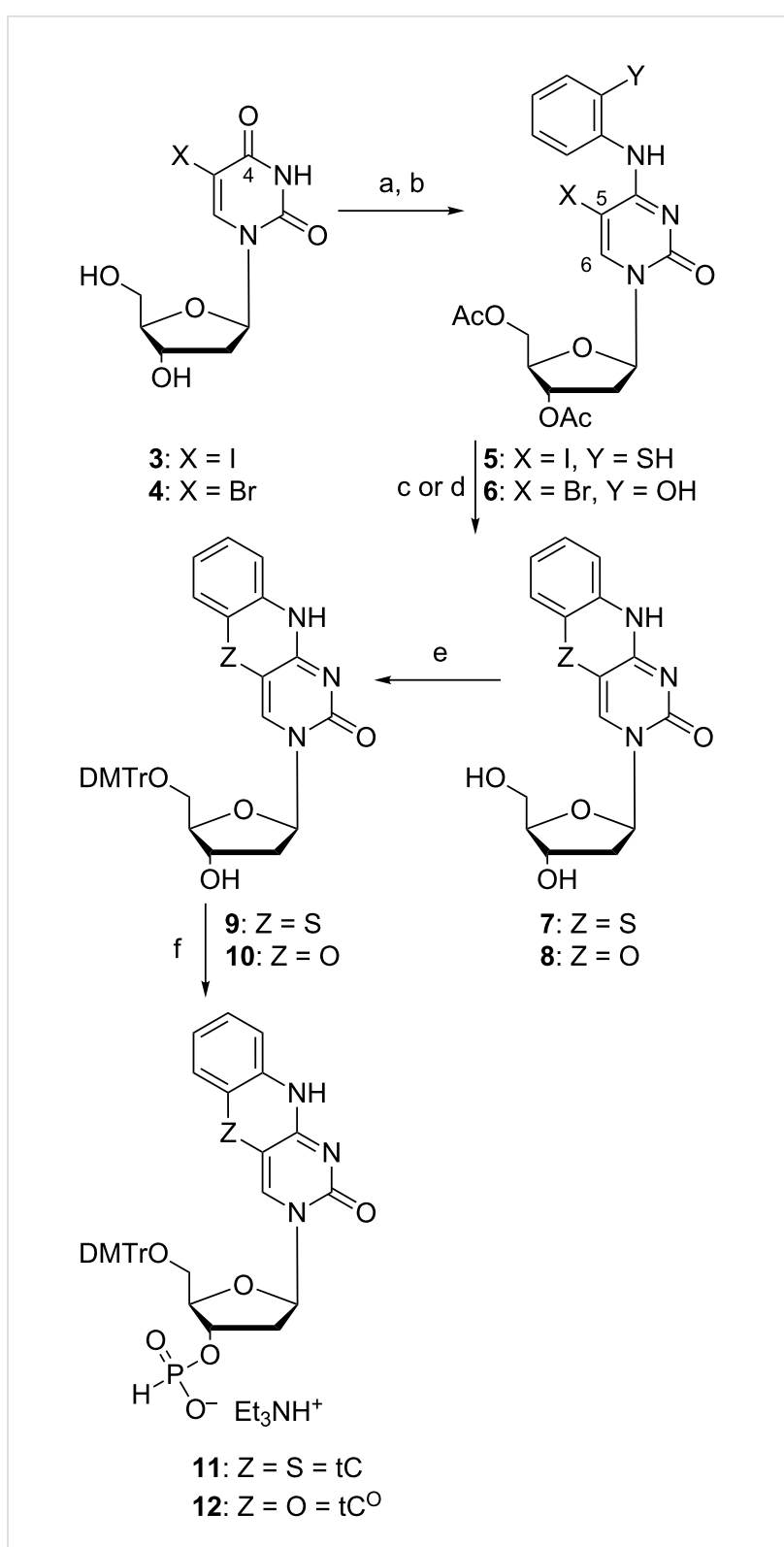

Scheme 2: Synthesis of protected tC and $\mathrm{tC}^{\mathrm{O}}$ deoxyribose phosphonates [41]. (a) $\mathrm{Ac}_{2} \mathrm{O}$, pyridine, rt; (b) 2-mesitylenesulfonyl chloride, TEA, then 2-aminothiophenol or 2-aminophenol, DBU, rt, $27 \%$ and $54 \%$ yield, respectively, over two steps; (c) $t$-BuOK in $\mathrm{EtOH}$, reflux, $38 \%$; (d) $\mathrm{NH}_{3}$ in $\mathrm{MeOH}$, rt, then 10 equiv of $\mathrm{KF}$, EtOH, reflux; (e) 4,4'dimethoxytrityl chloride, pyridine, rt, yielding $50 \%$ of compound 10 over three steps; (f) 2-chloro-4H-1,3,2,-benzodioxaphosphorin-4-one, pyridine, $\mathrm{DCM}, 0{ }^{\circ} \mathrm{C}, 71 \%$ over two steps and $80 \%$, respectively.

In 2009, we published the first base-base FRET system using $\mathrm{tC}^{\mathrm{O}}$ and $\mathrm{tC}_{\text {nitro }}$ [14]. Nitro groups introduce an increased charge-transfer character to chromophores, which generally results in absorption at lower energies $[38,45]$. Hence, $\mathrm{tC}_{\text {nitro }}$ was envisioned to be able to accept the energy transferred from $\mathrm{tC}$ or $\mathrm{tC}^{\mathrm{O}}$, and, thus serve as a FRET acceptor. The synthesis of $\mathrm{tC}_{\text {nitro }}$ followed the procedure of Roth et al. [39] to furnish the aromatic core $\mathbf{1 3}$ (Scheme 3). Compound 13 was then glycosy- 


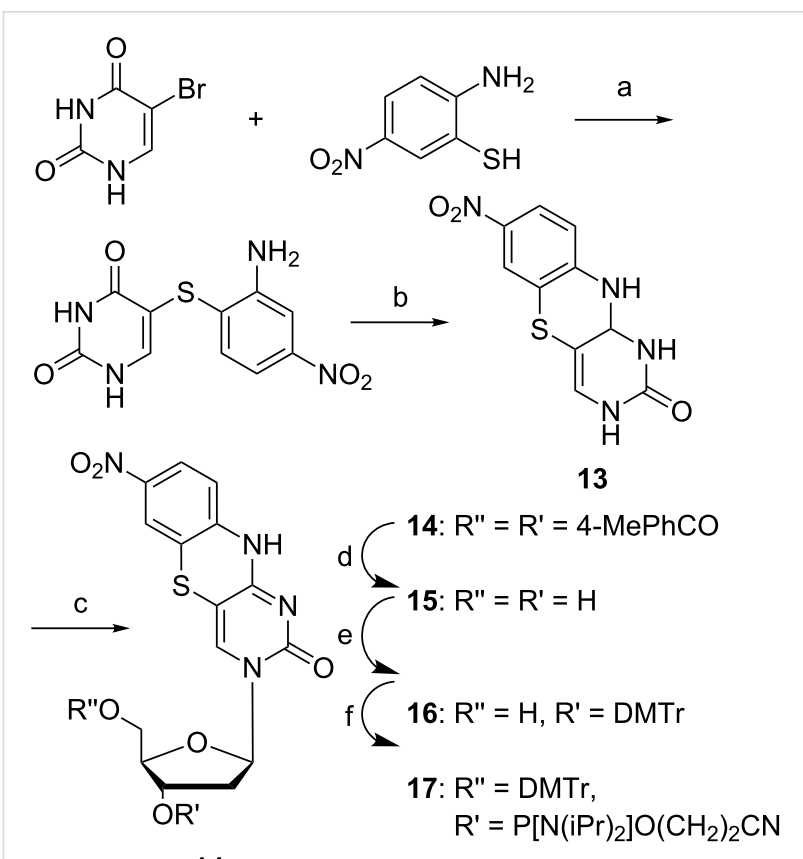

14

Scheme 3: Synthesis of protected $\mathrm{tC}_{\text {nitro }}$ deoxyribose phosphoramidite [14]. a) aq $\mathrm{NaOH}, 24 \mathrm{~h}$, reflux; b) $\mathrm{EtOH}, \mathrm{HCl}, 24 \mathrm{~h}$, reflux, 15\% over two steps; c) DMF, toluene, 3,5-di-O-p-toluoyl-a-D-erythro-pentofuranosyl, $\mathrm{NaH}, 18 \mathrm{~h}, \mathrm{rt}, 11 \%$; d) $\mathrm{MeONa}, \mathrm{MeOH}, 18 \mathrm{~h}, \mathrm{rt}, 71 \%$; e) pyridine, DMAP, DMTr-Cl, 18 h, rt, 74\%; f) DCM, DIPEA, 2-cyanoethyl$\mathrm{N}, \mathrm{N}$-diisopropylchlorophosphoramidite, $1 \mathrm{~h}, \mathrm{rt}, 93 \%$.

lated by making the sodium salt and reacting it with Hoffer's $\alpha$-chloro sugar yielding 14 in $11 \%$ yield after isolation [46]. The $p$-toluoyl protection groups were cleaved by sodium methoxide in $\mathrm{MeOH}$, which yielded the free nucleoside $\mathbf{1 5}$ in $71 \%$. Standard DMTr protection furnished compound $\mathbf{1 6}$ which was then activated for oligonucleotide solid-phase synthesis (SPS) by phosphitylation using CEP-Cl. The total yield of $\mathrm{tC}_{\text {nitro }}$ deoxyribose phosphoramidite was $0.8 \%$ over 6 steps where the acidcatalyzed cyclization as well as the glycosylation proved challenging. The latter two steps proceeded with a yield of $15 \%$ or less (17, Scheme 3).

A new synthetic approach to access substituted tricyclic cytosines was envisioned in 2014 by Rodgers et al. (Scheme 4). This protocol increased the yield of the parent compound tC from $10 \%$ up to $43 \%$ in the glycosylation step of the previously prepared tC nucleobase (Scheme 4) [47]. This was achieved by activation of the aromatic core of compounds $18 \mathbf{a}-\mathbf{c}$ via trimethylsilylation using BSA (bis(trimethylsilyl)acetamide) [47], instead of the sodium-salt method [42]. The deoxyribosylation was then achieved using the same Hoffer's $\alpha$-chloro sugar, but in presence of a Lewis acid yielding the protected nucleosides 19a-c [48]. The cleavage of the protection groups was achieved with sodium methoxide to furnish compounds $\mathbf{2 0 a}-\mathbf{c}$.

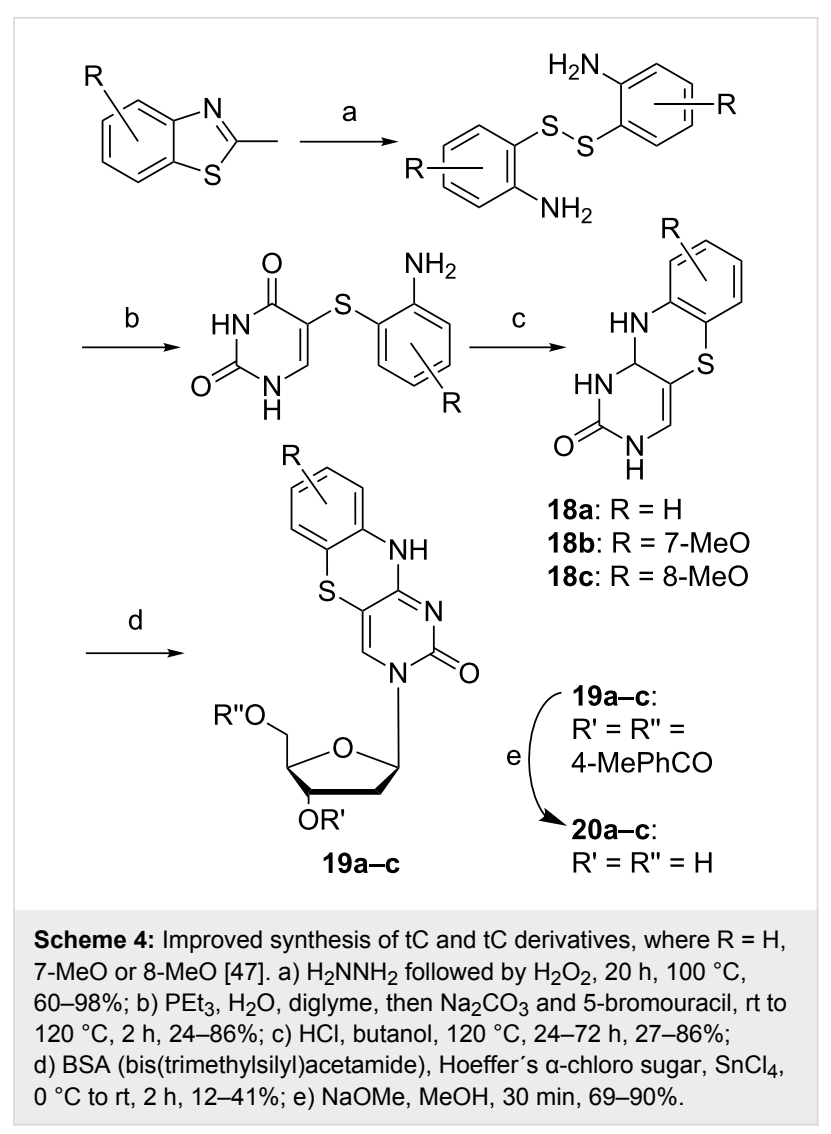

The improved synthetic route to $\mathrm{tC}^{\mathrm{O}}$ derivatives started from the same 3',5'-di-O-acetyl-5-bromo-2'-deoxyuridine (21, Scheme 5) as Lin et al. used, but was instead activated for a condensation using Appel chemistry [41,49]. Compound 21 was activated using $\mathrm{PPh}_{3}$ in $\mathrm{CCl}_{4}$ which converts the $\mathrm{O} 4$ to a 4-Cl and used in situ with various substituted 2-aminophenols in the presence of the strong base DBU which resulted in compounds 22a-e. A subsequent protection group removal yielded compounds 23a-e and made the scaffold ready for cyclization. Initially, CsF was used in place of KF, however, the hygroscopic nature of $\mathrm{CsF}$ made it impractical to handle. Instead, $\mathrm{KF}$ was used in combination with 18-crown-6 in anhydrous diglyme which furnished compounds $24 \mathbf{a}-\mathbf{e}$ in modest 3-24\% yields after isolation (Scheme 5) [47].

Recently, our group gained interest in RNA chemistry and therefore revisited the synthesis of $\mathrm{tC}^{\mathrm{O}}$ containing a ribose unit instead of a deoxyribose [50]. By simply activating the $\mathrm{O} 4$ of 25 (Scheme 6) using 2-mesitylenesulfonyl chloride and DIPEA in $\mathrm{MeCN}$, the successful condensation with 2-aminophenol was achieved and afforded compound $\mathbf{2 6}$ in $71 \%$ yield. The cyclization of 26, which previously suffered from low yields, was effectively obtained in $86 \%$ yield by using an excess of KF in ethanol and microwave heating at $140{ }^{\circ} \mathrm{C}$. Conveniently, at the same time all the three acetyl protecting groups were cleaved 


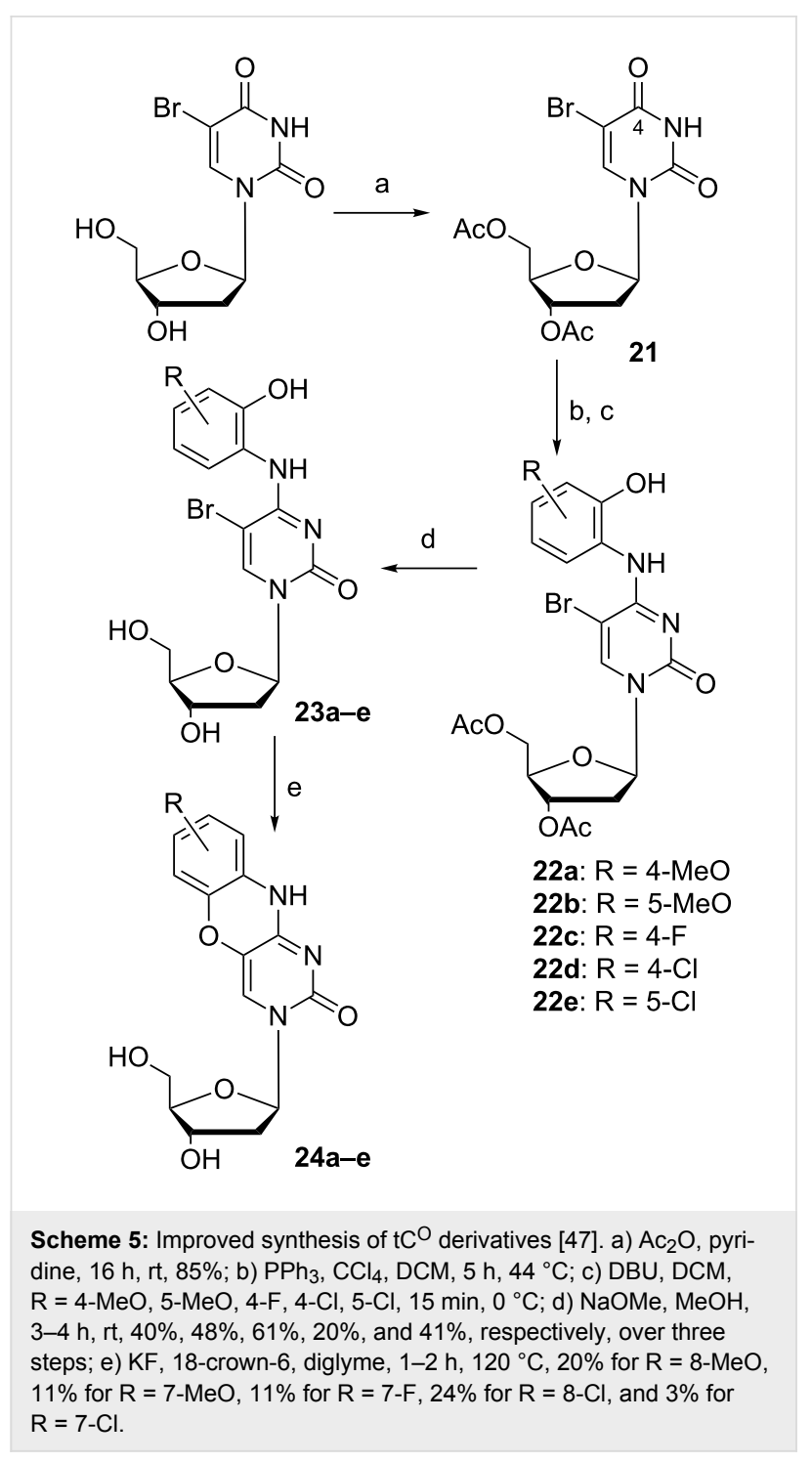

and the free nucleobase was isolated via precipitation. A 5 -DMTr protection followed by 2 '-TBDMS protection and phosphitylation using $\mathrm{CEP}-\mathrm{Cl}$ generated the fully protected monomer ready for solid-phase synthesis [50]. The complete synthesis of the RNA building block of $\mathrm{tC}^{\mathrm{O}}$ was in this way achieved over five steps with a total yield of $28 \%$, improved from the four step DNA building block synthesis of $\mathrm{tC}^{\mathrm{O}}$ by Lin et al. of $22 \%$ [41].

\section{Synthesis of adenine analogues for base-base FRET}

Buhr et al. were interested in developing modified adenosines that could thermodynamically stabilize double-stranded nucleic acids [51]. In 1999, a short synthesis article regarding quadracyclic adenine, qA, was published, however, it lacked a full experimental procedure (Scheme 7). The synthesis started from 6-chloro-7-iodo-7-deazapurine functionalized at the N-9 posi-

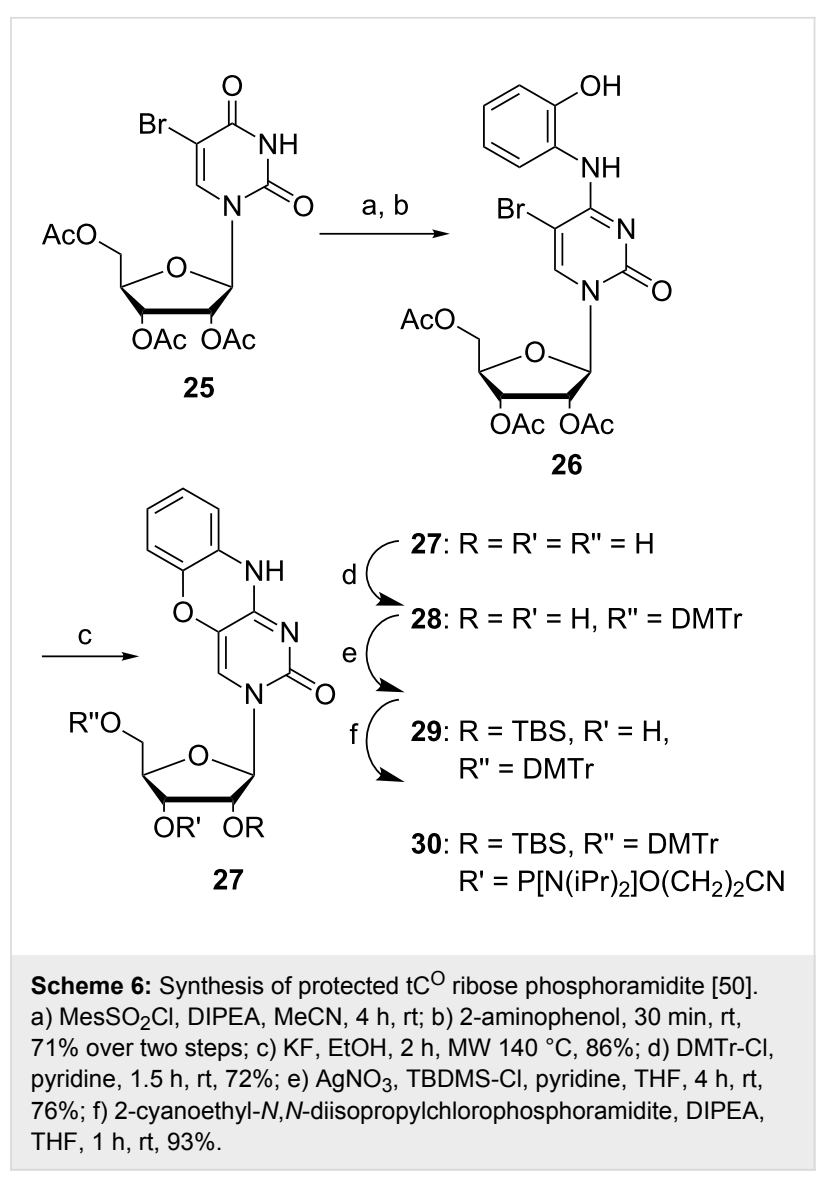

tion with Hoffer's $\alpha$-chloro sugar (31, Scheme 7). This material was functionalized further using a Stille coupling to afford a mono-Boc-protected $o$-iodoaniline $\mathbf{3 2}$ in $68 \%$ yield after isolation [52]. The cyclization was performed via nucleophilic aromatic substitution with DBU and DABCO. Presumably DABCO activates the chlorine and modifies it into a better leaving group allowing the sterically hindered base DBU to abstract a proton from the protected aniline which allows the cyclization. Standard Boc deprotection using TFA gave compound 33 in $96 \%$ over two steps. This was followed by $p$-toluoyl deprotection using sodium methoxide in methanol to afford 34 in 64\% yield after isolation. Then, the material was protected with DMTr-Cl yielding the protected nucleoside in $65 \%$ yield. Subsequent phosphitylation followed by salt-formation finally furnished compound $\mathbf{3 5}$ in $52 \%$ over two steps.

Since the quadracyclic adenine presented an overall structural similarity with adenine and keeping a very rigid heterocyclic system suggesting few options for the molecule to decay from excited states via non-radiative processes, in 2012 we decided to re-synthesize the quadracyclic adenine according to the procedure of Buhr et al. (Scheme 8) [51,53]. However, in our hands the vital cyclization reaction starting from compound $\mathbf{3 6}$ (Scheme 8) never provided more than a $46 \%$ yield of 37 after 


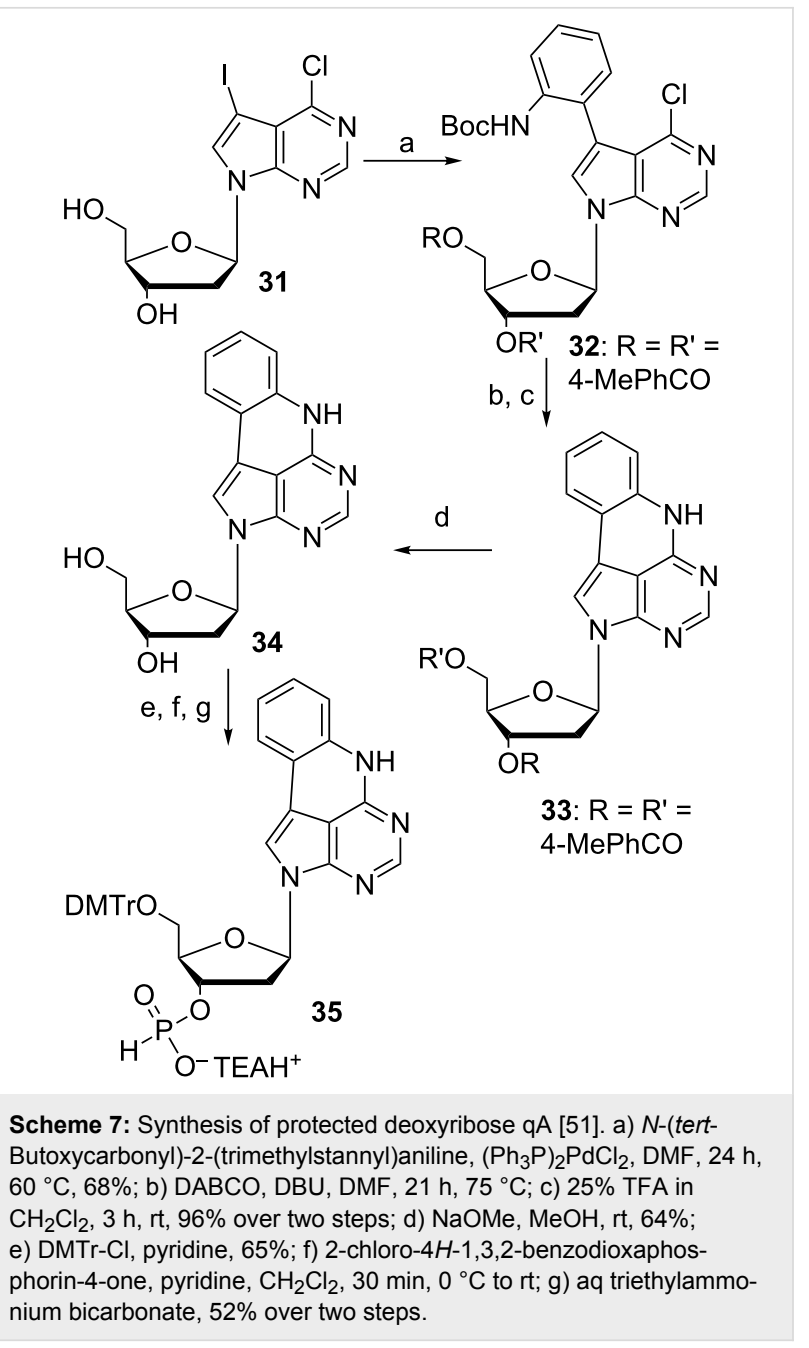

TFA deprotection of the Boc group compared to the previously reported $96 \%$ [51].

The base-pairing properties of qA with $\mathrm{T}$ and selectivity were found to be excellent. Moreover, the melting temperature of the oligonucleotides remained close to those of unmodified sequences indicating that $\mathrm{qA}$ is an excellent adenine analogue [53]. Unfortunately, the photophysical properties of qA were not satisfactory for an internal FRET fluorophore and, thus, we moved on by modifying the quadracyclic aromatic core but leaving the advantageous base-pairing properties. To this end, we needed to develop a more straightforward and versatile synthetic route. The Stille coupling was changed to a Suzuki-Miyaura coupling and the cyclization was performed directly starting from the free aniline nitrogen, as we found that Boc protection was required only for cyclization when using DBU and DABCO. To faster screen a larger set of new compounds for fluorescent properties we envisioned that it was unnecessary to carry the entire sugar moiety through the synthesis. Thus, by alkylation of 6-chloro-7-iodo-7-deazapurine (41, Scheme 9) followed by a Miyaura-style borylation of compound 42, inspired by Thompson et al. we achieved compound $\mathbf{4 3}$ in a yield of $77 \%$ over two steps [54]. This material was functionalized in two different studies: first by using pyridinetype anilines and later with R-group modifications to the top ring (Scheme 9) [55,56].

Among the quadracyclic adenine analogues in those two studies we found qAN1 to be a promising candidate as a FRET donor due to its high quantum yield of 0.18 (vide infra) [55]. To

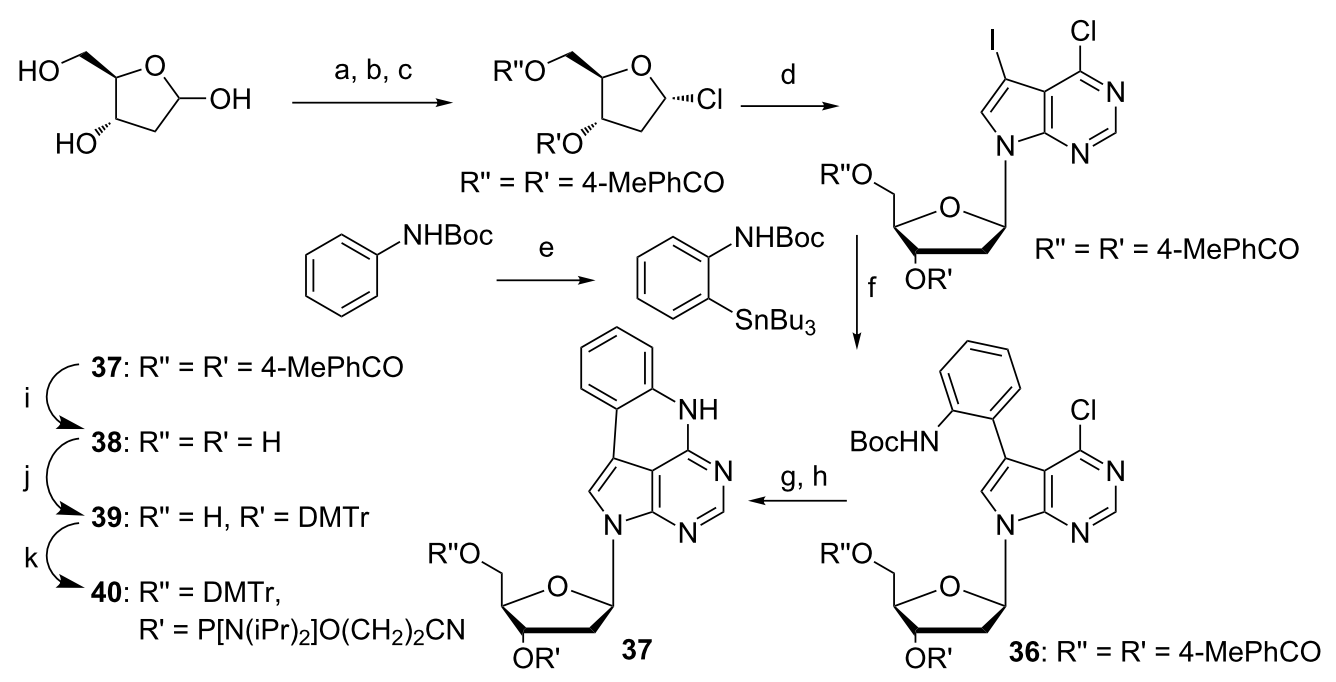

Scheme 8: Synthesis of protected deoxyribose qA for DNA SPS [53]. a) AcCl, $\mathrm{MeOH}, \mathrm{rt}, 40 \mathrm{~min}$; b) p-toluoyl chloride, pyridine, overnight, $0{ }^{\circ} \mathrm{C}$ to rt; c) $\mathrm{AcCl}, \mathrm{AcOH}, \mathrm{H}_{2} \mathrm{O}, 0{ }^{\circ} \mathrm{C}, 36 \%$ over three steps; d) $\mathrm{NaH}, \mathrm{MeCN}, 30 \mathrm{~min}$, rt, then $2 \mathrm{~h}$ at $60{ }^{\circ} \mathrm{C}, 73 \%$; e) $t-\mathrm{BuLi}, \mathrm{SnBuCl} 3, \mathrm{THF}, 2 \mathrm{~h},-78{ }^{\circ} \mathrm{C}, 65 \%$; f) $\mathrm{Pd}\left(\mathrm{PPh}_{3}\right)_{4}$, Cul, CsF, DMF, $1 \mathrm{~h}, 100{ }^{\circ} \mathrm{C}, 55 \%$; g) DABCO, DBU, DMF, $16 \mathrm{~h}, 75^{\circ} \mathrm{C}$; h) $25 \%$ TFA in $\mathrm{CH}_{2} \mathrm{Cl}_{2}, 1.5 \mathrm{~h}, 0{ }^{\circ} \mathrm{C}$ to rt, $46 \%$ over two steps; i) $\mathrm{NaOMe}, \mathrm{MeOH}$, overnight, rt, $61 \%$; j) DMTr-Cl, pyridine, $1 \mathrm{~h}, \mathrm{rt}, 68 \%$; k) 2-cyanoethyl- $\mathrm{N}, \mathrm{N}$-diisopropylchlorophosphoramidite, $\mathrm{DIPEA} \mathrm{CH}_{2} \mathrm{Cl}_{2}, 1.5 \mathrm{~h}$, $\mathrm{rt}, 79 \%$. 


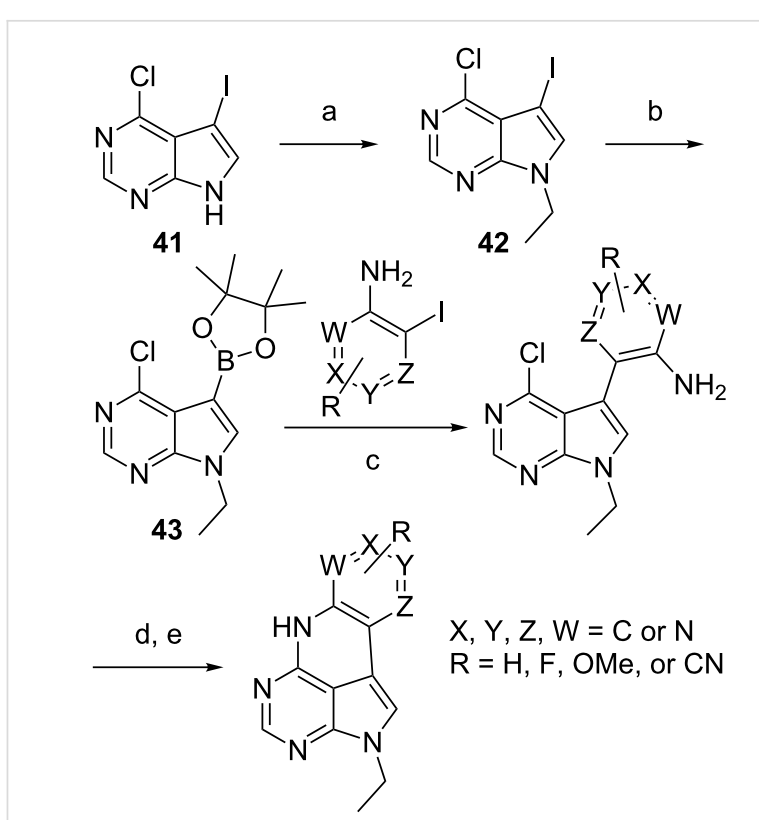

Scheme 9: Synthesis of qA derivatives. a) Etl, $\mathrm{Cs}_{2} \mathrm{CO}_{3}, \mathrm{DMF}, 4 \mathrm{~h}$, rt, $90 \%$; b) HBPin, $\mathrm{Pd}\left(\mathrm{PPh}_{3}\right)_{4}, \mathrm{Et}_{3} \mathrm{~N}, 1$, 4-dioxane, $24 \mathrm{~h}, 80{ }^{\circ} \mathrm{C}, 86 \%$; c) $\mathrm{PdCl}_{2}\left(\mathrm{PPh}_{3}\right)_{2}, \mathrm{~K}_{3} \mathrm{PO}_{4}, \mathrm{MeCN}, \mathrm{H}_{2} \mathrm{O}, 80^{\circ} \mathrm{C}, 2 \mathrm{~h}, 56-86 \%$; d) TMS-Cl, THF, 30 min, rt; e) LiHMDS, THF, $100{ }^{\circ} \mathrm{C}, 3 \mathrm{~h}, 33-71 \%$.

develop an adenine acceptor for qAN1, a similar approach as for the tricyclic cytosines was performed, i.e., the introduction of a nitro functionality in the outer ring of qA. In an extensive investigation $\mathrm{qA}_{\text {nitro }}$ was synthesized and characterized and we found it, indeed, to be a suitable FRET acceptor for qAN1 (vide infra). The full synthesis scheme and characterization of this adenine-adenine analogue FRET pair was recently published by our group [25]. The synthetic approach was to first construct a common intermediate that could be used for various Suzukicoupling partners similar to what we previously reported [55], by first protecting 6-chloro-7-iodo-7-deazapurine with tertbutyldimethylsilyloxymethyl (TBDMSOM) in $86 \%$ yield over two steps (44, Scheme 10). A Miyaura-type borylation afforded the common intermediate $\mathbf{4 5}$ in $\mathbf{9 1 \%}$ yield and Suzuki coupling was then achieved efficiently for both 2-amino-3-iodopyridine as well as 2-iodo-4-nitroaniline in (46) 95\% and (47) $86 \%$ yield, respectively. The activation of the exocyclic amine was achieved by using $\mathrm{AcCl}$ which provided a more robust cyclization using LiHMDS than if activating the amine using TMS-Cl. This furnished compounds $\mathbf{4 8}$ and $\mathbf{4 9}$ in $89 \%$ and $87 \%$ yield, respectively, over two steps. The subsequent Boc protection gave compound $\mathbf{5 0}$ in $89 \%$ and compound $\mathbf{5 1}$ in $83 \%$ yield. The quantitative TBDMSOM deprotection set the stage for a glycosylation using Hoffer's $\alpha$-chloro sugar and compounds $\mathbf{5 2}$ and 53 provided the desired $\beta$-anomer after purification in $69 \%$ and $55 \%$ yield, respectively. Global deprotection using sodium methoxide followed by standard DMTr-protection and phosphitylation provides the activated monomers for solid-phase synthesis [25]. The overall yield of qAN1 and $\mathrm{qA}_{\text {nitro }}$ phosphoramidite was $19 \%$ and $14 \%$, respectively, which is significantly higher than our previous synthesis of qA ( $6 \%$ overall yield) starting from 6-chloro-7-iodo-7-deazapurine (Scheme 10).

\section{Photophysical properties of tricyclic cytosine analogues in nucleic acids}

The tricyclic cytosine base analogues 1,3-diaza-2-oxophenothiazine $(\mathrm{tC})$, and its oxo homologue, 1,3-diaza-2-oxophenoxazine $\left(\mathrm{tC}^{\mathrm{O}}\right.$ ) (Scheme 1 and Scheme 2 ) are both excellent fluorescent base analogues as well as donors for base-base FRET in nucleic acids [14,29-31,36]. Extensive evidences that both these base analogues mimic the behavior of natural cytosine have been found using UV-vis [30] and NMR spectroscopy [36], e.g., exchanging cytosine for one of them results in a virtually unperturbed B-form DNA helix. Importantly and as the first fluorescent base analogue with such properties, tC shows high and stable quantum yields (around 20\%) both in monomeric form, in single- as well as in double-stranded DNA [29,30]. The quantum yield of $\mathrm{tC}^{\mathrm{O}}$ in different environments is even higher than those of $\mathrm{tC}$ [31]. While slightly dependent on the neighboring base environment they are still very stable compared to other common fluorescent base analogues $[15,16]$. The absorption maxima of $\mathrm{tC}$ and $\mathrm{tC}^{\mathrm{O}}$ in DNA are found at approximately 395 and $365 \mathrm{~nm}$ (Figure 3) [30,31], respectively, and, thus, are well separated from the absorption of the natural nucleobases. The emission of $\mathrm{tC}$ and $\mathrm{tC}^{\mathrm{O}}$ in duplex DNA display large Stokes shifts, cover a broad wavelength region and the maxima are found at 505 and $450 \mathrm{~nm}$ (Figure 3), respectively [30,31]. Their spectral envelopes, which are an important factor for the overlap integral in FRET, are robust to changes in the local environment.

The fluorescence decays of $\mathrm{tC}$ are all monoexponential in single- as well as in double-stranded DNA resulting in a single lifetime of 5-7 ns depending on the sequence surroundings [30]. For $\mathrm{tC}^{\mathrm{O}}$ single-stranded surroundings generally result in biexponential decays, whereas duplex surroundings, as in the case for $\mathrm{tC}$, result in single fluorescence lifetimes (3-5 ns) [31]. High and stable quantum yields and single lifetimes in duplexes along with firm stacking are properties that make $\mathrm{tC}$ and $\mathrm{tC}^{\mathrm{O}}$ excellent FRET donors. In order to make evaluation of FRET data more exact, through a high precision in the orientation factor $\left(\kappa^{2}\right)$, we have also determined the direction of the transition dipole moments of $\mathrm{tC}$ and $\mathrm{tC}^{\mathrm{O}}\left(35^{\circ}\right.$ and $33^{\circ}$ clockwise from the molecular long-axis as represented in Scheme 1 and Scheme 2, respectively) [31,35]. To complete the first base-base FRET pair there was a need for a FRET acceptor that could match $\mathrm{tC}$ and/or $\mathrm{tC}^{\mathrm{O}}$. To this end we developed the nitroversion of $\mathrm{tC}$, 7-nitro-1,3-diaza-2-oxophenothiazine ( $\left.\mathrm{tC}_{\mathrm{nitro}}\right)$ (Scheme 3) $[14,38,45]$. From UV-vis spectroscopy we showed 

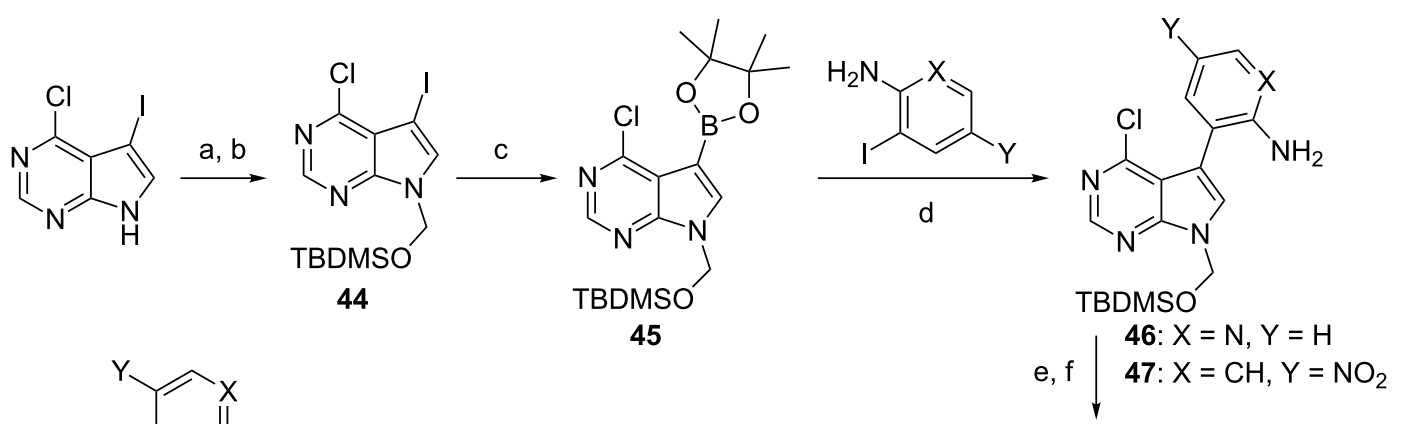<smiles></smiles>

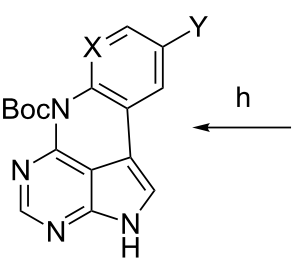<smiles>[Y]c1ccc2c(c1)-c1cn(COC(C)C)c3ncnc(c13)N(C)CC2</smiles><smiles>[Y]c1ccc2c(c1)C1=CN(COC(C)C)c3ncnc(c3-2)N1</smiles>

52: $\mathrm{X}=\mathrm{N}, \mathrm{Y}=\mathrm{H}$

50: $\mathrm{X}=\mathrm{N}, \mathrm{Y}=\mathrm{H}$

48: $\mathrm{X}=\mathrm{N}, \mathrm{Y}=\mathrm{H}$

53: $\mathrm{X}=\mathrm{CH}, \mathrm{Y}=\mathrm{NO}_{2}$

51: $X=\mathrm{CH}, Y=\mathrm{NO}_{2}$

49: $X=\mathrm{CH}, Y=\mathrm{NO}_{2}$<smiles></smiles>

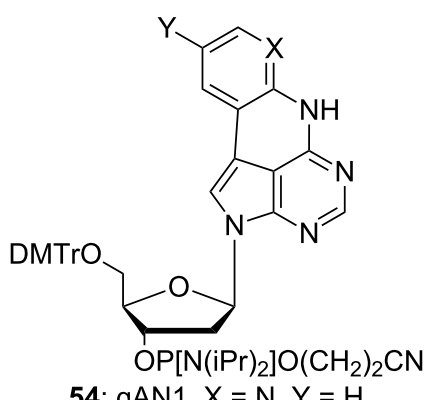

54: qAN1, $X=N, Y=H$

55: $\mathrm{qA}_{\text {nitro }}, \mathrm{X}=\mathrm{CH}, \mathrm{Y}=\mathrm{NO}_{2}$

Scheme 10: Synthesis of quadracyclic adenine base-base FRET pair. a) $\mathrm{HCHO}, \mathrm{NaOH}, \mathrm{MeCN}, \mathrm{H}_{2} \mathrm{O}, 50^{\circ} \mathrm{C}, 1 \mathrm{~h}$; b) TBDMS-OTf, pyridine, $1 \mathrm{~h}, 0{ }^{\circ} \mathrm{C}$ to rt, $86 \%$ over two steps; c) HBPin, $\mathrm{Pd}\left(\mathrm{PPh}_{3}\right)_{4}, \mathrm{Et}_{3} \mathrm{~N}, 1,4$-dioxane, $24 \mathrm{~h}, 80^{\circ} \mathrm{C}, 91 \%$; d) $\mathrm{PdCl}_{2}\left(\mathrm{PPh}_{3}\right)_{2}, \mathrm{~K}_{2} \mathrm{CO}_{3}, \mathrm{MeCN}, \mathrm{H}_{2} \mathrm{O}, 80^{\circ} \mathrm{C}, 2 \mathrm{~h}, 86-95 \%$; e) AcCl, pyridine, $\mathrm{CH}_{2} \mathrm{Cl}_{2}, 3 \mathrm{~h}$, rt; f) LiHMDS, THF, $100{ }^{\circ} \mathrm{C}, 2-6 \mathrm{~h}, 87-89 \%$; g) Boc $2 \mathrm{O}$, DMAP, THF, $10 \mathrm{~h}$, rt, 83-89\%; h) ethane-1,2-diamine, TBAF, THF, $2 \mathrm{~h}, 0{ }^{\circ} \mathrm{C}$ to rt, $97-100 \%$; i) NaH, Hoffer's a-chloro sugar, MeCN, $2 \mathrm{~h}, 0{ }^{\circ} \mathrm{C}$ to rt, 55-69\%; j) $\mathrm{NaOMe}, \mathrm{MeCN}$ or $\mathrm{MeOH}, 1 \mathrm{~h}, 50{ }^{\circ} \mathrm{C}, 81-99 \%$; k) DMTr-Cl, pyridine, $1.5 \mathrm{~h}$, rt, 55-75\%; I) 2-cyanoethyl- $\mathrm{N}, \mathrm{N}$-diisopropylchlorophosphoramidite, DIPEA, $\mathrm{CH}_{2} \mathrm{Cl}_{2}, 2 \mathrm{~h}, \mathrm{rt}, 87-90 \%$.

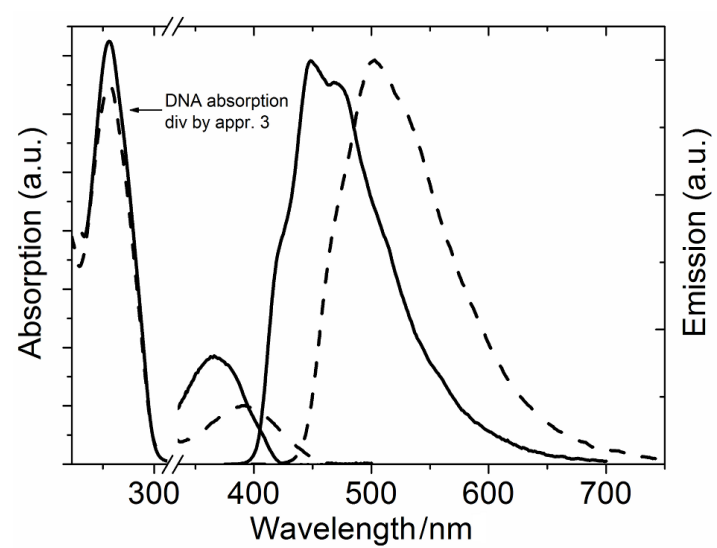

Figure 3: Absorption and emission of $\mathrm{tC}$ (dashed line) and $\mathrm{tC}^{\mathrm{O}}$ (solid line) in dsDNA. The absorption below $300 \mathrm{~nm}$ is divided by three to emphasize the absorption spectral features of the lowest energy absorption bands of $\mathrm{tC}$ and $\mathrm{tC}^{\mathrm{O}}$ that it, as do $\mathrm{tC}$ and $\mathrm{tC}^{\mathrm{O}}$, forms stable, $\mathrm{B}$-form duplexes and stacks firmly inside the DNA. It is a non-emissive chromophore that has an absorption maximum around $440 \mathrm{~nm}$ which overlaps well with the emission of both $\mathrm{tC}$ and $\mathrm{tC}^{\mathrm{O}}$, thus, making it a potential FRET acceptor for both of them [14]. The best spectral overlap is found between the emission of $\mathrm{tC}^{\mathrm{O}}$ and the absorption of $\mathrm{tC}_{\text {nitro }}$ giving a Förster radius $\left(R_{0}\right)$ of $27 \AA$ using an isotropic orientation factor, $\kappa^{2}=2 / 3$ [14]. Finally, for a high precision in orientation factor, i.e., to enable detailed structure investigations, we determined the direction of the lowest energy transition dipole moment of $\mathrm{tC}_{\text {nitro }}$ to be $25^{\circ}$ in the opposite direction compared to $\mathrm{tC}_{\mathrm{C}}$ and $\mathrm{tC}^{\mathrm{O}}$ (i.e., pointing towards the nitro group) [14].

As was mentioned in the synthesis part above, recently we also have developed $\mathrm{tC}^{\mathrm{O}}$ as an internal fluorophore for RNA systems [50]. The incorporation into RNA oligonucleotides and hybridi- 
zation with a complementary strand results in normal A-form RNA duplexes. Moreover, the useful absorptive and emissive spectral properties of $\mathrm{tC}^{\mathrm{O}}$ in DNA are retained in RNA. However, fluorescence decay data for $\mathrm{tC}^{\mathrm{O}}$ in RNA suggests a less rigidly stacked conformation in RNA and two lifetimes are normally needed to achieve a good fit of the decays. With virtually stable quantum yields of $20-25 \%$ inside duplex RNA, $\mathrm{tC}^{\mathrm{O}}$ is the brightest internal RNA fluorophore reported to date and, thus, a promising fluorescence reporter and/or FRET donor also in RNA systems [50].

\section{Photophysical properties of quadracyclic adenine analogues in nucleic acids}

Extending the repertoire of base-base FRET pairs to other nucleobases would provide researchers the opportunity of replacing any sequence position in a nucleic acid with a base analogue FRET donor or acceptor. This motivated us to venture into the development of adenine analogues. Quadracyclic adenine (qA) [51], the emission of which was first reported by our group, was our initial adenine analogue candidate [53]. It stabilizes the native B-form DNA and is selective for base pairing with thymine. The emissive properties are decent both for the monomer $\left(\Phi_{\mathrm{f}}=6.8 \%\right)$ and inside DNA even though the quantum yield is quenched in the latter case. However, the average brightness in duplex DNA is still higher than that of 2-aminopurine and together with the excellent base-paring properties it is still a highly useful, environment-sensitive fluorescent-base analogue [53].

Despite its excellent base-analogue properties, the low quantum yield of qA inside DNA disqualifies it for use as a base-base FRET donor. In order to maintain the base-analogue properties and achieve improved photophysical properties, we used quantum chemistry-supported design and developed a series of four, second generation, quadracyclic adenine analogues, qAN1-qAN4 (Scheme 9 and Scheme 10) [55,56]. As monomers, these compounds show significantly improved fluorescence properties. Importantly, one of the derivatives, qAN1, showed a high quantum yield in water (18\%) that was not excessively influenced by varying the solvent, indicating that qAN1 is not highly sensitive to the direct surroundings [55]. Once incorporated into DNA strands, qAN1 specifically basepairs to the complementary base, thymine, and allows formation of stable B-form DNA [25]. Moreover, the quantum yields inside DNA are significantly increased compared to those of qA. However, the quantum yields of qAN1 are slightly sensitive to the directly flanking bases with an average quantum yield of $6 \%$ in dsDNA [25]. The wavelength of the emission maximum found around $415 \mathrm{~nm}$ (Figure 4) in dsDNA is insensitive to the neighboring bases and the spectrum is more structured compared to the spectrum of monomeric qAN1, implying a firm stacking inside DNA [25]. The fluorescence lifetimes of qAN1 inside dsDNA show biexponential decays (average amplitude-weighted lifetimes ranging from 0.8 to $3.3 \mathrm{~ns}$ ) for a majority of investigated sequences as compared to triexponential decays in ssDNA [25]. Overall, with a brightness $\left(\Phi_{\mathrm{f}^{*}} \varepsilon=510 \mathrm{M}^{-1} \mathrm{~cm}^{-1}\right)$ inside DNA which is 29-times higher than for $\mathrm{qA}$, specificity towards $\mathrm{T}$ and a firm stacking inside B-form DNA, qAN1 represents an excellent base-base FRETdonor candidate. To complete the base-base FRET pair the acceptor $\mathrm{qA}_{\text {nitro }}$ (Scheme 10) was designed and synthesized [25]. Spectroscopy-based investigations of the base analogue properties of $\mathrm{qA}_{\text {nitro }}$ inside DNA suggest that this derivative of $\mathrm{qA}$ is an excellent A-analogue just like qAN1. The lowest absorption maximum for $\mathrm{qA}_{\text {nitro }}$ in DNA is located at $435 \mathrm{~nm}$ (Figure 4) with a molar absorptivity of $5400 \mathrm{M}^{-1} \mathrm{~cm}^{-1}$. As in the case of $\mathrm{tC}^{\mathrm{O}}$ and $\mathrm{tC}_{\text {nitro }}$ there is an excellent spectral overlap between the emission of qAN1 and the absorption of $\mathrm{qA}_{\text {nitro }}$ (Figure 4) resulting in a Förster radius (using an orientation factor $\kappa^{2}=2 / 3$ ) of $22 \AA$. This suggested that qAN1 and $\mathrm{qA}_{\text {nitro }}$ would constitute a good base-base FRET pair [25].

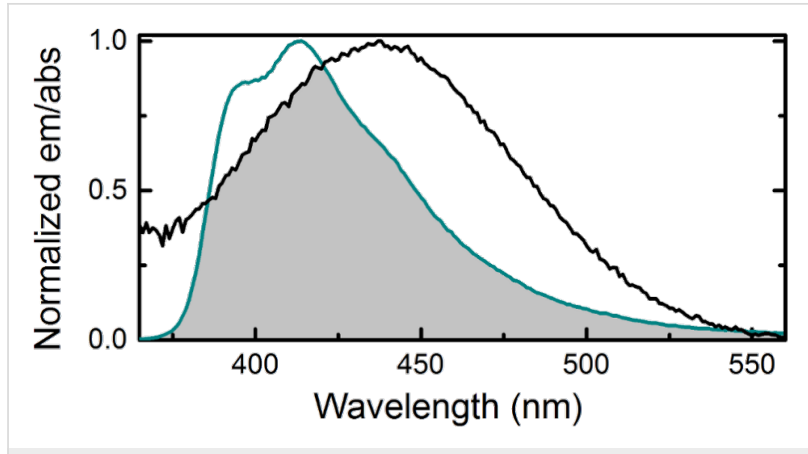

Figure 4: Spectral overlap between the emission of qAN1 (cyan) and the absorption of $\mathrm{qA}_{\text {nitro }}$ (black) in dsDNA. The shaded region constitutes the overlap integral ( $\mathrm{J}$ integral).

\section{Fluorescent base analogue FRET pairs inside DNA}

When using FRET theory on fluorophores/chromophores that replace nucleobases of a normal but static DNA, estimated energy-transfer efficiencies can be simulated using the structure parameters of the B-form duplex together with photophysical parameters of the fluorophores/chromophores. In this way we used the photophysical parameters we already had obtained for our two FRET pairs, $\mathrm{tC}^{\mathrm{O}}-\mathrm{tC}_{\text {nitro }}$ and $\mathrm{qAN} 1-\mathrm{qA}_{\text {nitro }}$, to design the best combination of donor and complementary acceptor-containing DNA oligonucleotides [14,25]. We found that eight DNA strands were sufficient: three donor $\left(\mathrm{tC}^{\mathrm{O}} / \mathrm{qAN} 1\right)$ strands, four acceptor $\left(\mathrm{tC}_{\text {nitro }} / \mathrm{qA}_{\text {nitro }}\right)$ strands and one unmodified strand serving as the complementary strand in donor-only reference samples. Combining these strands in an optimal way we covered distances of $2-13$ bases separating the donor and 
the acceptor. For each base separation the FRET efficiency was investigated both by steady-state and time-resolved emission measurements. The results of those show an excellent resemblance with our predicted values for a nucleobase FRET pair situated inside a static DNA: an overall sharp $\left(R^{6}\right)$ decrease in the FRET efficiency with increasing numbers of bases separating the donor and the acceptor with an overlaid sinusoidal curvature as a consequence of the effect of the helical nature of $\mathrm{B}$-form DNA on the orientation factor, $\kappa^{2}$ (Figure 5) [14,25]. Both, the measured sets of FRET efficiencies, the one for $\mathrm{tC}^{\mathrm{O}}-\mathrm{tC}_{\text {nitro }}$ as well as the one for $\mathrm{qAN} 1-\mathrm{qA}_{\text {nitro }}$, were fitted to an averaged, static B-form DNA model using an in-house built MATLAB script. The best fits agree excellently with the measured data and suggest that our two FRET pairs are indeed rigidly stacked inside DNA and serve as excellent distance and orientation dependent FRET probes (Figure 5) [14,25]. In the fit we used the associated phase angle (angle between the transition dipole moments of the donor and the acceptor) and the spectral overlap $\left(J_{\mathrm{DA}}\right)$ as the fitting parameters. The phase angles for the $\mathrm{tC}^{\mathrm{O}}-\mathrm{tC}_{\text {nitro }}$ and the $\mathrm{qAN} 1-\mathrm{qA}_{\text {nitro }}$ FRET pairs were $67^{\circ}$ and $33^{\circ}$, respectively, that are in good agreement with the experimentally determined one for the cytosine analogue FRET pair $\left(58^{\circ}\right)$ and the TDDFT-estimated one for the adenine analogue FRET pair $\left(41^{\circ}\right)[14,25]$. Also the spectral overlap integrals show high similarity to the values resulting from the best fit. Taken together these two FRET pairs comprise excellent tools to study detailed structure, dynamics and conformational changes of DNA. An additional advantage with our cytosine and adenine analogue FRET pairs is that they, as a result of their spectral features, can be combined with each other, i.e.,
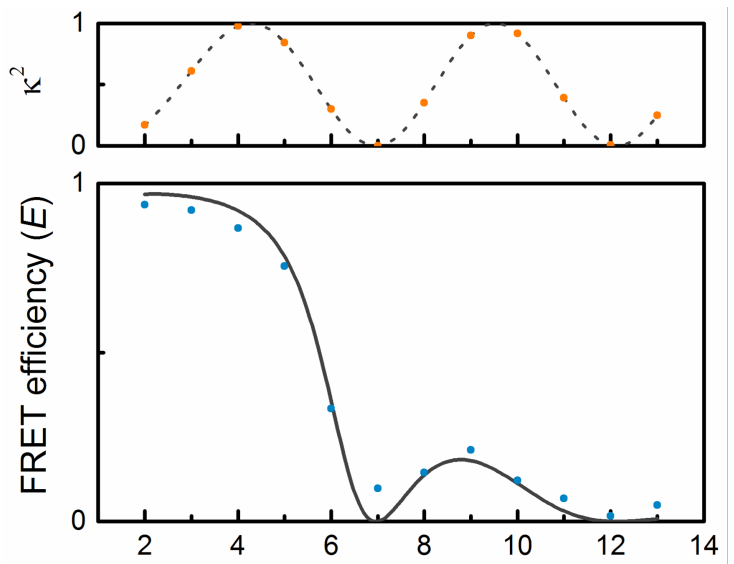

Distance between donor and acceptor (no. bp.)

Figure 5: Example of typical FRET efficiency as a function of number of base pairs separating the donor and acceptor (data, blue dots, is an average of steady-state and time-resolved measurements of the FRET pair qAN1 and $\left.q A_{\text {nitro }}\right)$. The line shows a curve fitted to the data based on FRET theory. The top graph shows how the orientation factor, $\mathrm{k}^{2}$, varies with number of base pairs separating the donor and acceptor.
$\mathrm{qA}_{\text {nitro }}$ can replace $\mathrm{tC}_{\text {nitro }}$ as an acceptor of $\mathrm{tC}^{\mathrm{O}}$, and, similarly, $\mathrm{tC}_{\text {nitro }}$ can replace $\mathrm{qA}_{\text {nitro }}$ as an acceptor of qAN1 [25]. A useful advantage of this is that we can now perform base-base FRET between any sequence positions inside duplex DNA.

Recently Sugiyama and co-workers reported a nucleobase-analogue FRET pair that consists of the 2-aminothieno[3,4d]pyrimidine G-mimic deoxyribonucleoside ( ${ }^{\text {th }} \mathrm{dG}$ ) (see Figure 2) [23], developed by the Tor lab, as an energy donor and 1,3-diaza-2-oxophenothiazine (tC), developed by our lab, as an energy acceptor [57]. This G-C analogue FRET pair also displays the general characteristics of an energy efficiency curve of base-base FRET and is able to emit cyan-green light from its acceptor molecule tC. The authors used this FRET pair to study a change from B-to-Z-form DNA using the color and intensity change of the combined donor and acceptor emission [57].

\section{FRETmatrix}

To enable detailed studies using our FRET pairs we have developed the freely available software FRETmatrix [58]. It consists of two parts, one that predicts FRET efficiencies from structural input and one that can calculate the most probable structure using measured FRET efficiencies as input.

The first part is useful in the design of a study, as it can predict the change in FRET efficiency between two base analogues upon a structural change of the DNA (for example caused by protein binding). This allows the user to make informed choices of where in a DNA duplex to incorporate the modified bases to get useful FRET-change responses. The second, more powerful part provides structural information based on the FRET efficiencies measured between base analogues positioned on opposite sides of a constraint site. The constraint site can, for example, be a protein-induced kink in the DNA. The software needs the DNA sequence together with photophysical data of the FRET pair and measured FRET efficiencies as input. Then, assuming the rest of the DNA is unchanged, the geometrical parameters of the constraint site can be obtained. This is possible since the base analogues are rigidly positioned inside the DNA (Figure 1c) and the FRET efficiencies depend on the relative distance and angle between them (see Equations 1-3). FRETmatrix, in this way provides a convenient possibility to study structural changes of nucleic acids in solution using only emission measurements [58]. For example, in a small demonstration study we have shown that the method can be used to resolve the structure of a 3A (3 adenine) bulge [58]. The same bulge has been studied by other groups as well, using different techniques and with similar results [59-61]. An elegant and groundbreaking way to study and use detailed FRET has also been reported by Seidel et al. By assuring that the external dyes in use 
are truly free to rotate (see Figure $1 \mathrm{~b}$; isotropic orientation) an orientation factor, $\kappa^{2}$, of $2 / 3$ can be assumed. In combination with advanced computer modeling, high accuracy structural parameters can thus be resolved from FRET measurements $[62,63]$. In conclusion, the FRETmatrix (base-base FRET) and Seidel's methodology are in a way two extremes, firmly vs randomly oriented probes, both giving high control of the $\kappa^{2}$ value which in turn facilitates high detail structure information determination.

\section{Studying nucleic acid conformation and con- formational changes using base-base FRET}

Many biologically important processes such as binding of transcription factors to DNA, polymerase-DNA interactions during replication, gene regulatory systems and structure variation due to changes in conditions (e.g., B-to-Z-form DNA), generally involve conformational changes where base-base FRET can be used with an advantage. The possibility to monitor both, distance and orientation of these conformational changes and inherent dynamics of the systems in real time increases the level of detail accessible in the FRET investigation. Over the less than ten years they have been available, nucleobase analogue FRET pairs have been able to monitor several important processes including transcription and DNA repair. Here we give a short summary of a number of those applications.

\section{Higher detail structure information investigations}

DNA exists in a variety of conformations depending on conditions. Z-DNA, a GC-repeat rich, thermodynamically less preferred, left-handed helical conformation that is favored by cytosine methylation is known to form in vivo under negative supercoiling or high salt concentrations [64-68]. Circular dichroism is traditionally the predominant method to investigate Z-DNA and to monitor conformational changes from B-to-Zform DNA [68-72]. However, the development of nucleobase analogue-based FRET provided an opportunity to sense the significant orientational and distance changes for the B-to-Z-transition in real time using significantly smaller sample amounts. Therefore, we set out to use the $\mathrm{tC}^{\mathrm{O}}-\mathrm{tC}_{\text {nitro }}$ FRET pair to develop new methodologies to investigate Z-form DNA [73]. Two different DNA constructs were selected: one of them containing a $(\mathrm{GC})_{7}$ and the other a $(\mathrm{GC})_{5}$. The former is a hairpin which is designed to be able to transform completely into Z-form DNA at high salt concentrations and the latter is able to form a $\mathrm{B}-\mathrm{Z}$ DNA junction under similar, high salt conditions. The $\mathrm{tC}^{\mathrm{O}}-\mathrm{tC}_{\text {nitro }}$ FRET pair was incorporated at three different base separations $(4,6$, and 8 bases between donor and acceptor, respectively). The results show significant changes in the FRET efficiencies upon B-to-Z-DNA transition (e.g., from 35 to 8\%) that can, not only, be used to monitor the presence of Z-form DNA but also to determine the rate constants for these transi- tions [73]. We showed in this investigation that the FRET-based method to study Z-form DNA reduces the amount of sample needed by almost three orders of magnitude compared to the most commonly used CD methodology [73].

Recently we used our adenine analogue FRET pair, qAN1- $\mathrm{qA}_{\text {nitro }}$, to study the conformational change of B-form DNA upon interaction with the established minor groove binder netropsin [25]. Netropsin is an archetypal minor groove ligand that binds short (4-5 bp) AT-rich sequences [74-76]. In our investigation we first measured the FRET efficiencies, using both steady-state and time-resolved emission, between qAN1 and $\mathrm{qA}_{\text {nitro }}$ separated by $2-13$ bp in a B-form DNA. Thereafter, we added netropsin until site saturation and again measured the FRET efficiencies (Figure 6), now for base separations of 4-11 bp [25].

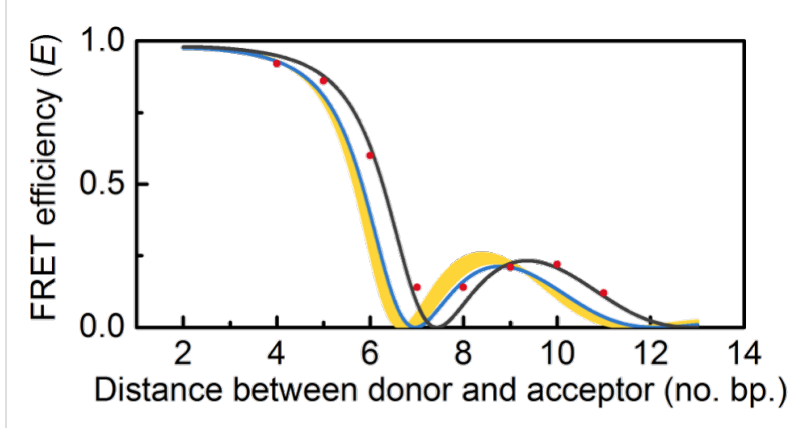

Figure 6: FRET efficiency as a function of number of base pairs separating the donor ( $q A N 1)$ and acceptor $\left(q A_{\text {nitro }}\right)$. Red dots mark the measured FRET efficiency with netropsin bound. The black line shows the best fit to the data based on FRET theory. The blue line shows the curve for B DNA. The yellow area depicts the range possible if each netropsin molecule overwinds the DNA as stated in previous literature.

Upon netropsin binding the measured base-base FRET efficiencies change significantly in their orientational component (extreme values are shifted to larger base separations) and also slightly in their distance component (shows up as a higher amplitude for the maximum around 9-10 bp). Fitting these FRET data (Figure 6) points to the best possible DNA helical twist and rise values results in a decrease in twist and rise by $2^{\circ}$ and $0.25 \AA$, respectively [25]. This is in contrast to previously reported values showing slight increases in helical twist and rise measured, for example, by sedimentation [77], gel electrophoresis [78,79], X-ray crystallography [74] and magnetic tweezers [75]. In our investigation we modeled the general appearance of a FRET curve resulting from such, small, helical twist and rise increases (yellow area in Figure 6) and in this way were able to establish that our data unambiguously show decreases in twist and rise [25]. One important difference with our system compared to most previous studies is the fact that we use short DNAs that easily can relax the strain induced by the netropsin 
binding. Our netropsin study shows the general strength and potential of base-base FRET to investigate even very small changes in distance and orientation and the finding warrants further studies of this structural change using a larger set of DNA sequences containing netropsin binding sites.

\section{Qualitative base-base FRET to investigate vital cel- lular processes}

As clearly shown above, base-base FRET is a powerful method to obtain structure information with high structure detail. However, one of its obvious and even more straightforward applications is merely for monitoring whether a certain process involves a conformational change or not. A few examples of such applications are described below.

In a collaborative investigation with Falkenberg and Gustafsson, we investigated the role of the transcription factor A (TFAM) in the mitochondrial transcription machinery $[80,81]$. The investigation, also involving an extensive use of gel electrophoresis studies, shows that TFAM, in contrast to previous reports, indeed is a core component of the machinery. In the study our FRET pair $\mathrm{tC}^{\mathrm{O}}-\mathrm{tC}_{\text {nitro }}$ was site-specifically incorporated in various positions close to the HSP1 transcription initiation site. The results suggest that when TFAM binds to the DNA, it causes significant structural changes [80]. These changes are clearly visible in the $\mathrm{tC}^{\mathrm{O}}-\mathrm{tC}_{\text {nitro }}$ FRET data that also indicate that the conformational changes could be consistent with DNA breathing. Moreover, the data demonstrated that the structural changes upon binding of TFAM near the transcription initiation site are the result of sequence-independent binding to DNA. The investigation establishes the potential of using base-base FRET for studying nucleic acid conformations in vital cellular processes without perturbing the system under study.

In another report using the $\mathrm{tC}^{\mathrm{O}-}-\mathrm{tC}_{\text {nitro }}$ FRET pair as a probe of protein interaction, Ansari et al. investigated the DNA damage repair system [82]. Here the FRET pair is used to better understand the conformational dynamics along the DNA-lesion recognition trajectory. The $\mathrm{tC}^{\mathrm{O}}-\mathrm{tC}_{\text {nitro }}$ FRET pair was incorporated on both sides of mismatched regions in a DNA to report on conformational changes upon DNA repair protein Rad4 interaction. The FRET data obtained support a model in which Rad4 binds to the mismatched part causing a "twist-open" mechanism and demonstrates the potential of base-base FRET in short time-scale kinetics investigations [82].

\section{Conclusion}

Base-base FRET has a great potential as a detailed structure and dynamics tool in biomolecular sciences. It serves as an interesting complement to FRET pairs based on external fluoro- phores enabling higher structure resolution and monitoring of a different distance range with high accuracy. With the recent advent of new base-base FRET pairs, the coming years offer great prospects for increased use of such methodology. The combination of base-base FRET and single-molecule-based FRET on nucleic acids with external probes as developed by Seidel et al. [4] comprise a highly interesting opportunity to investigate structure and dynamics of nucleic acid containing systems. Recent progress in the field of fluorescent base analogues also starts to close the gap in brightness to external fluorophores like Cy-, Alexa- and ATTO-dyes and the development of a base analogue with properties that are satisfactory for single molecule use would open up completely new possibilities to study the detailed structure, dynamics and conformational changes of one of the key players in life: nucleic acids.

\section{ORCID ${ }^{\circledR}$ iDs}

Sangamesh Sarangamath - https://orcid.org/0000-0001-8430-6426 Moa S. Wranne - https://orcid.org/0000-0003-3315-8288 Morten Grøtli - https://orcid.org/0000-0003-3621-4222

L. Marcus Wilhelmsson - https://orcid.org/0000-0002-2193-6639

\section{References}

1. Foster, M. P.; McElroy, C. A.; Amero, C. D. Biochemistry 2007, 46, 331-340. doi:10.1021/bi0621314

2. Holbrook, S. R. Annu. Rev. Biophys. 2008, 37, 445-464. doi:10.1146/annurev.biophys.36.040306.132755

3. Preus, S.; Wilhelmsson, L. M. ChemBioChem 2012, 13, 1990-2001. doi:10.1002/cbic. 201200400

4. Kalinin, S.; Peulen, T.; Sindbert, S.; Rothwell, P. J.; Berger, S.; Restle, T.; Goody, R. S.; Gohlke, H.; Seidel, C. A. M. Nat. Methods 2012, 9, 1218-1225. doi:10.1038/nmeth.2222

5. König, I.; Zarrine-Afsar, A.; Aznauryan, M.; Soranno, A.; Wunderlich, B.; Dingfelder, F.; Stüber, J. C.; Plückthun, A.; Nettels, D.; Schuler, B. Nat. Methods 2015, 12, 773-779. doi:10.1038/nmeth.3475

6. Sustarsic, M.; Kapanidis, A. N. Curr. Opin. Struct. Biol. 2015, 34, 52-59. doi:10.1016/j.sbi.2015.07.001

7. Lakowicz, J. R. Principles of Fluorescence Spectroscopy, 2nd ed.; Springer: New York, 2006. doi:10.1007/978-0-387-46312-4

8. Dolghih, E.; Roitberg, A. E.; Krause, J. L. J. Photochem. Photobiol., A 2007, 190, 321-327. doi:10.1016/j.jphotochem.2006.11.009

9. Norman, D. G.; Grainger, R. J.; Uhrin, D.; Lilley, D. M. J. Biochemistry 2000, 39, 6317-6324. doi:10.1021/bi992944a

10. Iqbal, A.; Wang, L.; Thompson, K. C.; Lilley, D. M. J.; Norman, D. G. Biochemistry 2008, 47, 7857-7862. doi:10.1021/bi800773f

11. Hurley, D. J.; Tor, Y. J. Am. Chem. Soc. 2002, 124, 13231-13241. doi:10.1021/ja020172r

12. Lewis, F. D.; Zhang, L.; Zuo, X. J. Am. Chem. Soc. 2005, 127, 10002-10003. doi:10.1021/ja0524402

13. Iqbal, A.; Arslan, S.; Okumus, B.; Wilson, T. J.; Giraud, G.; Norman, D. G.; Ha, T.; Lilley, D. M. J. Proc. Natl. Acad. Sci. U. S. A. 2008, 105, 11176-11181. doi:10.1073/pnas.0801707105

14. Börjesson, K.; Preus, S.; El-Sagheer, A. H.; Brown, T.; Albinsson, B.; Wilhelmsson, L. M. J. Am. Chem. Soc. 2009, 131, 4288-4293. doi:10.1021/ja806944w 
15. Wilhelmsson, L. M. Q. Rev. Biophys. 2010, 43, 159-183. doi:10.1017/S0033583510000090

16. Sinkeldam, R. W.; Greco, N. J.; Tor, Y. Chem. Rev. 2010, 110, 2579-2619. doi:10.1021/cr900301e

17. Kato, T.; Kashida, H.; Kishida, H.; Yada, H.; Okamoto, H.; Asanuma, H. J. Am. Chem. Soc. 2013, 135, 741-750. doi:10.1021/ja309279w

18. Beija, M.; Afonso, C. A. M.; Martinho, J. M. G. Chem. Soc. Rev. 2009, 38, 2410-2433. doi:10.1039/b901612k

19. Shindy, H. A. Dyes Pigm. 2017, 145, 505-513. doi:10.1016/j.dyepig.2017.06.029

20. Ward, D. C.; Reich, E.; Stryer, L. J. Biol. Chem. 1969, 244, 1228-1237.

21. Ben Gaied, N.; Glasser, N.; Ramalanjaona, N.; Beltz, H.; Wolff, P.; Marquet, R.; Burger, A.; Mély, Y. Nucleic Acids Res. 2005, 33, 1031-1039. doi:10.1093/nar/gki253

22. Matarazzo, A.; Hudson, R. H. E. Tetrahedron 2015, 71, 1627-1657. doi:10.1016/j.tet.2014.12.066

23. Shin, D.; Sinkeldam, R. W.; Tor, Y. J. Am. Chem. Soc. 2011, 133, 14912-14915. doi:10.1021/ja206095a

24. Suzuki, A.; Takahashi, N.; Okada, Y.; Saito, I.; Nemoto, N.; Saito, Y. Bioorg. Med. Chem. Lett. 2013, 23, 886-892. doi:10.1016/j.bmcl.2012.11.029

25. Wranne, M. S.; Füchtbauer, A. F.; Dumat, B.; Bood, M.; El-Sagheer, A. H.; Brown, T.; Gradén, H.; Grøtli, M.; Wilhelmsson, L. M. J. Am. Chem. Soc. 2017, 139, 9271-9280. doi:10.1021/jacs.7b04517

26. Driscoll, S. L.; Hawkins, M. E.; Balis, F. M.; Pfleiderer, W.; Laws, W. R. Biophys. J. 1997, 73, 3277-3286. doi:10.1016/S0006-3495(97)78352-8

27. Dumas, A.; Luedtke, N. W. Nucleic Acids Res. 2011, 39, 6825-6834. doi:10.1093/nar/gkr281

28. Tokugawa, M.; Masaki, Y.; Canggadibrata, J. C.; Kaneko, K.; Shiozawa, T.; Kanamori, T.; Grøtli, M.; Wilhelmsson, L. M.; Sekine, M.; Seio, K. Chem. Commun. 2016, 52, 3809-3812. doi:10.1039/C5CC09700B

29. Wilhelmsson, L. M.; Holmén, A.; Lincoln, P.; Nielsen, P. E.; Nordén, B. J. Am. Chem. Soc. 2001, 123, 2434-2435. doi:10.1021/ja0025797

30. Sandin, P.; Wilhelmsson, L. M.; Lincoln, P.; Powers, V. E. C.; Brown, T.; Albinsson, B. Nucleic Acids Res. 2005, 33, 5019-5025. doi:10.1093/nar/gki790

31. Sandin, P.; Börjesson, K.; Li, H.; Mårtensson, J.; Brown, T.; Wilhelmsson, L. M.; Albinsson, B. Nucleic Acids Res. 2008, 36 157-167. doi:10.1093/nar/gkm1006

32. Berry, D. A.; Jung, K.-Y.; Wise, D. S.; Sercel, A. D.; Pearson, W. H.; Mackie, H.; Randolph, J. B.; Somers, R. L. Tetrahedron Lett. 2004, 45, 2457-2461. doi:10.1016/j.tetlet.2004.01.108

33. Wojciechowski, F.; Hudson, R. H. E. J. Am. Chem. Soc. 2008, 130, 12574-12575. doi:10.1021/ja804233g

34. Mata, G.; Luedtke, N. W. J. Am. Chem. Soc. 2015, 137, 699-707. doi:10.1021/ja508741u

35. Wilhelmsson, L. M.; Sandin, P.; Holmén, A.; Albinsson, B.; Lincoln, P.; Nordén, B. J. Phys. Chem. B 2003, 107, 9094-9101. doi:10.1021/jp034930r

36. Engman, K. C.; Sandin, P.; Osborne, S.; Brown, T.; Billeter, M.; Lincoln, P.; Nordén, B.; Albinsson, B.; Wilhelmsson, L. M. Nucleic Acids Res. 2004, 32, 5087-5095. doi:10.1093/nar/gkh844

37. Sandin, P.; Lincoln, P.; Brown, T.; Wilhelmsson, L. M. Nat. Protoc. 2007, 2, 615-623. doi:10.1038/nprot.2007.80

38. Preus, S.; Börjesson, K.; Kilså, K.; Albinsson, B.; Wilhelmsson, L. M. J. Phys. Chem. B 2010, 114, 1050-1056. doi:10.1021/jp909471b

39. Roth, B.; Schloemer, L. A. J. Org. Chem. 1963, 28, 2659-2672. doi:10.1021/jo01045a042
40. Roth, B.; Hitchings, G. H. J. Org. Chem. 1961, 26, 2770-2778. doi:10.1021/jo01066a035

41. Lin, K.-Y.; Jones, R. J.; Matteucci, M. J. Am. Chem. Soc. 1995, 117, 3873-3874. doi:10.1021/ja00118a026

42. Kazimierczuk, Z.; Cottam, H. B.; Revankar, G. R.; Robins, R. K. J. Am. Chem. Soc. 1984, 106, 6379-6382. doi:10.1021/ja00333a046

43. Schaller, H.; Weimann, G.; Lerch, B.; Khorana, H. G. J. Am. Chem. Soc. 1963, 85, 3821-3827. doi:10.1021/ja00906a021

44. Beaucage, S. L.; Caruthers, M. H. Tetrahedron Lett. 1981, 22 , 1859-1862. doi:10.1016/S0040-4039(01)90461-7

45. Preus, S.; Kilså, K.; Wilhelmsson, L. M.; Albinsson, B. Phys. Chem. Chem. Phys. 2010, 12, 8881-8892. doi:10.1039/C000625D

46. Hoffer, M. Chem. Ber. 1960, 93, 2777-2781. doi:10.1002/cber.19600931204

47. Rodgers, B. J.; Elsharif, N. A.; Vashisht, N.; Mingus, M. M.; Mulvahill, M. A.; Stengel, G.; Kuchta, R. D.; Purse, B. W. Chem. - Eur. J. 2014, 20, 2010-2015. doi:10.1002/chem.201303410

48. Niedballa, U.; Vorbrueggen, H. J. Org. Chem. 1974, 39, 3668-3671. doi:10.1021/jo00939a011

49. Appel, R. Angew. Chem., Int. Ed. Engl. 1975, 14, 801-811. doi:10.1002/anie.197508011

50. Füchtbauer, A. F.; Preus, S.; Börjesson, K.; McPhee, S. A.; Lilley, D. M. J.; Wilhelmsson, L. M. Sci. Rep. 2017, 7, No. 2393. doi:10.1038/s41598-017-02453-1

51. Buhr, C. A.; Matteucci, M. D.; Froehler, B. C. Tetrahedron Lett. 1999, 40, 8969-8970. doi:10.1016/S0040-4039(99)01875-4

52. Nair, V.; Turner, G. A.; Chamberlain, S. D. J. Am. Chem. Soc. 1987, 109, 7223-7224. doi:10.1021/ja00257a071

53. Dierckx, A.; Miannay, F.-A.; Ben Gaied, N.; Preus, S.; Björck, M.; Brown, T.; Wilhelmsson, L. M. Chem. - Eur. J. 2012, 18, 5987-5997. doi:10.1002/chem.201103419

54. Thompson, A. L. S.; Kabalka, G. W.; Akula, M. R.; Huffman, J. W. Synthesis 2005, 547-550. doi:10.1055/s-2005-861791

55. Dumat, B.; Bood, M.; Wranne, M. S.; Lawson, C. P.; Larsen, A. F.; Preus, S.; Streling, J.; Gradén, H.; Wellner, E.; Grøtli, M.; Wilhelmsson, L. M. Chem. - Eur. J. 2015, 21, 4039-4048. doi:10.1002/chem.201405759

56. Larsen, A. F.; Dumat, B.; Wranne, M. S.; Lawson, C. P.; Preus, S.; Bood, M.; Gradén, H.; Wilhelmsson, L. M.; Grøtli, M. Sci. Rep. 2015, 5, No. 12653. doi:10.1038/srep12653

57. Han, J. H.; Yamamoto, S.; Park, S.; Sugiyama, H. Chem. - Eur. J. 2017, 23, 7607-7613. doi:10.1002/chem.201701118

58. Preus, S.; Kilså, K.; Miannay, F.-A.; Albinsson, B.; Wilhelmsson, L. M. Nucleic Acids Res. 2013, 41, e18. doi:10.1093/nar/gks856

59. Wozniak, A. K.; Schröder, G. F.; Grubmüller, H.; Seidel, C. A. M.; Oesterhelt, F. Proc. Natl. Acad. Sci. U. S. A. 2008, 105, 18337-18342. doi:10.1073/pnas.0800977105

60. Gohlke, C.; Murchie, A. I. H.; Lilley, D. M. J.; Clegg, R. M. Proc. Natl. Acad. Sci. U. S. A. 1994, 91, 11660-11664. doi:10.1073/pnas.91.24.11660

61. Zacharias, M.; Hagerman, P. J. J. Mol. Biol. 1995, 247, 486-500. doi:10.1006/jmbi.1995.0155

62. Dimura, M.; Peulen, T. O.; Hanke, C. A.; Prakash, A.; Gohlke, H.; Seidel, C. A. M. Curr. Opin. Struct. Biol. 2016, 40, 163-185. doi:10.1016/j.sbi.2016.11.012

63. Peulen, T.-O.; Opanasyuk, O.; Seidel, C. A. M. J. Phys. Chem. B 2017, 121, 8211-8241. doi:10.1021/acs.jpcb.7b03441 
64. Wang, A. H.-J.; Quigley, G. J.; Kolpak, F. J.; Crawford, J. L.; van Boom, J. H.; van der Marel, G.; Rich, A. Nature 1979, 282, 680-686. doi:10.1038/282680a0

65. Rich, A.; Zhang, S. Nat. Rev. Genet. 2003, 4, 566-572. doi:10.1038/nrg1115

66. Liu, R.; Liu, H.; Chen, X.; Kirby, M.; Brown, P. O.; Zhao, K. Cell 2001, 106, 309-318. doi:10.1016/S0092-8674(01)00446-9

67. Pohl, F. M.; Jovin, T. M. J. Mol. Biol. 1972, 67, 375-396. doi:10.1016/0022-2836(72)90457-3

68. González, V. M.; Fuertes, M. A.; Pérez, J. M.; Alonso, C. Eur. Biophys. J. 1998, 27, 417-423. doi:10.1007/s002490050150

69. Chen, C.-w..; Knop, R. H.; Cohen, J. S. Biochemistry 1983, 22, 5468-5471. doi:10.1021/bi00293a002

70. Sheardy, R. D.; Levine, N.; Marotta, S.; Suh, D.; Chaires, J. B. Biochemistry 1994, 33, 1385-1391. doi:10.1021/bi00172a014

71. Sheardy, R. D.; Suh, D.; Kurzinsky, R.; Doktycz, M. J.; Benight, A. S.; Chaires, J. B. J. Mol. Biol. 1993, 231, 475-488. doi:10.1006/jmbi.1993.1295

72. Sheardy, R. D.; Winkle, S. A. Biochemistry 1989, 28, 720-725. doi:10.1021/bi00428a046

73. Dumat, B.; Larsen, A. F.; Wilhelmsson, L. M. Nucleic Acids Res. 2016, 44, e101. doi:10.1093/nar/gkw114

74. Kopka, M. L.; Yoon, C.; Goodsell, D.; Pjura, P.; Dickerson, R. E. Proc. Natl. Acad. Sci. U. S. A. 1985, 82, 1376-1380. doi:10.1073/pnas.82.5.1376

75. Lipfert, J.; Klijnhout, S.; Dekker, N. H. Nucleic Acids Res. 2010, 38 , 7122-7132. doi:10.1093/nar/gkq598

76. Premvardhan, L.; Maurizot, J.-C. Eur. Biophys. J. 2010, 39, 781-787. doi:10.1007/s00249-009-0550-x

77. Triebel, H.; Bär, H.; Geuther, R.; Burckhardt, G. Netropsin-induced changes of DANN supercoiling; sedimentation studies. In Analytical Ultracentrifugation; Behlke, J., Ed.; Progress in Colloid and Polymer Science, Vol. 99; Steinkopff Verlag: Dresden, 1995; pp 45-54. doi:10.1007/BFb0114069

78. Snounou, G.; Malcolm, A. D. B. J. Mol. Biol. 1983, 167, 211-216. doi:10.1016/S0022-2836(83)80043-6

79. Rettig, M.; Germann, M. W.; Wang, S.; Wilson, W. D. ChemBioChem 2013, 14, 323-331. doi:10.1002/cbic.201200706

80. Shi, Y.; Dierckx, A.; Wanrooij, P. H.; Wanrooij, S.; Larsson, N.-G.; Wilhelmsson, L. M.; Falkenberg, M.; Gustafsson, C. M. Proc. Natl. Acad. Sci. U. S. A. 2012, 109, 16510-16515. doi:10.1073/pnas.1119738109

81. Posse, V.; Hoberg, E.; Dierckx, A.; Shahzad, S.; Koolmeister, C.; Larsson, N.-G.; Wilhelmsson, L. M.; Hällberg, B. M.; Gustafsson, C. M. Nucleic Acids Res. 2014, 42, 3638-3647. doi:10.1093/nar/gkt1397

82. Velmurugu, Y.; Chen, X.; Sevilla, P. S.; Min, J.-H.; Ansari, A. Proc. Natl. Acad. Sci. U. S. A. 2016, 113, E2296-E2305. doi:10.1073/pnas.1514666113

\section{License and Terms}

This is an Open Access article under the terms of the Creative Commons Attribution License (http://creativecommons.org/licenses/by/4.0), which permits unrestricted use, distribution, and reproduction in any medium, provided the original work is properly cited.

The license is subject to the Beilstein Journal of Organic Chemistry terms and conditions:

(http://www.beilstein-journals.org/bjoc)

The definitive version of this article is the electronic one which can be found at: doi:10.3762/bjoc. 14.7 